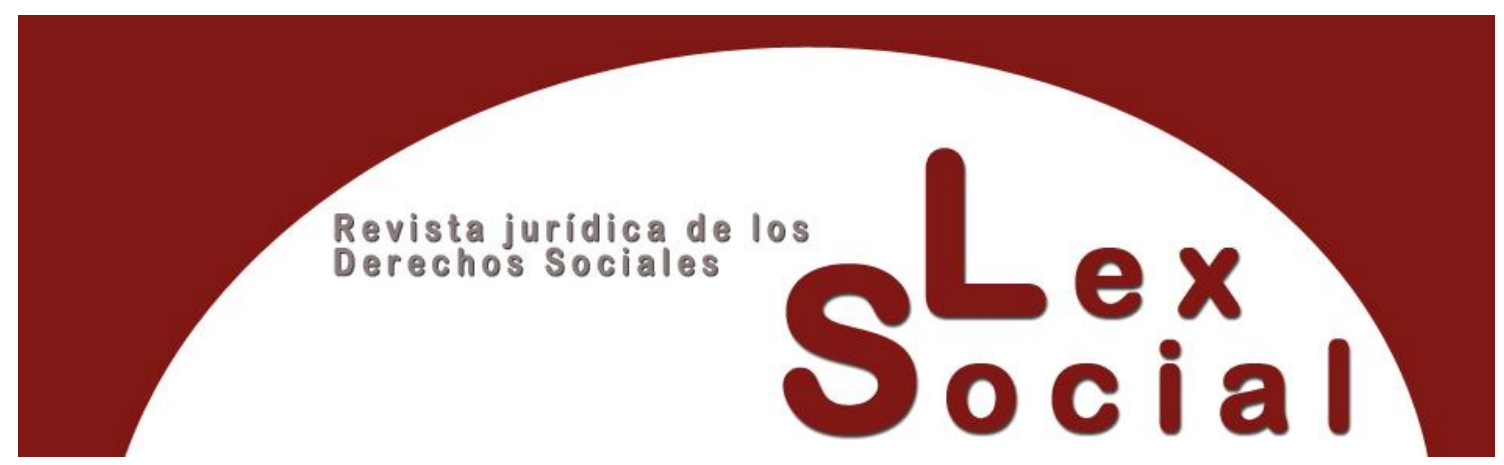

\title{
LAS HUELGAS ILEGALES: ESPECIAL REFERENCIA A LA HUELGA POLÍTICO-SOCIAL
}

\section{THE ILLEGAL STRIKES: PARTICULAR REFERENCE TO THE POLITICAL-SOCIAL STRIKE}

\author{
JOSÉ LUIS MONEREO PÉREZ \\ Catedrático de Derecho del Trabajo y Seguridad Social \\ Universidad de Granada \\ https://orcid.org/0000-0002-0230-6615 \\ POMPEYO GABRIEL ORTEGA LOZANO \\ Profesor Ayudante Doctor de Derecho del Trabajo y de la Seguridad Social \\ Universidad de Granada \\ https://orcid.org/0000-0001-9880-4231
}

Cómo citar este trabajo: Monereo Pérez, J.L. y Ortega Lozano, P.G. (2021). Las huelgas ilegales: especial referencia a la huelga político-social. Lex Social, Revista De Derechos Sociales, 11 (2), 353-399. https://doi.org/10.46661/lexsocial.5926

\section{RESUMEN}

Tratamos de abordar, desde una perspectiva jurídica, las huelgas ilegales, con especial incidencia en la huelga político-social. Asimismo, hacemos referencia a algunas propuestas de lege ferenda, al olvidado proyecto de ley orgánica y a la más reciente resolución del Tribunal Supremo, concluyendo este estudio con una serie de reflexiones generales.

Palabras Clave: Huelga, ilegal, abusiva, política, social.

\section{(cc) BY-NC-SA}




\begin{abstract}
We intend to tackle, from a legal point of view, the illegal strikes, with special impact in the politics-social strike. Additionally, we make reference to some proposals of lege ferenda, to the forgotten organic bill and to the most recent reference of the Supreme Court, concluding this study with a serial of general reflections.
\end{abstract}

KEYWORDS: Strike, illegal, abusive, politics, social

SUMARIO

\title{
I. Introducción
}

II. Modalidades de huelga en atención a diversos criterios: especial referencia al criterio teleológico. Huelga laboral y huelga político-social

III. Huelga ilegal y huelga abusiva: intereses objeto de tutela y algunas propuestas de lege ferenda

$I V$. Huelgas políticas y referencias al olvidado proyecto de ley orgánica

V. Huelga legal por tener proyección en las relaciones laborales y no únicamente por motivos políticos: referencia a la última sentencia dictada por el Tribunal Supremo

VI. Balance y perspectivas: reflexiones generales

VII. Bibliografía

"El peligro más grave que siempre debe enfrentar una sociedad es el deseo de los que poseen el poder de prohibir las ideas y la conducta que pueden perturbarlos en su posesión [...]. La libertad siempre entraña el coraje de resistir las exigencias de la fuerza, cuando ha llegado un momento que se considera decisivo [...]"

HAROLD J. LASKI ${ }^{1}$

\section{INTRODUCCIÓN}

La huelga es la manifestación principal del conflicto "declarado"2. La huelga es, ante todo, un fenómeno social de no colaboración, mucho antes de ser una institución jurídicopositiva $^{3}$. Es un fenómeno bastante complejo, expresión de un malestar que puede

\footnotetext{
${ }^{1}$ LASKI, H.J.: La libertad en el Estado moderno, edición, y estudio preliminar a cargo de J.L. Monereo Pérez, Granada, Comares (Col. Crítica del Derecho), 2020, pp. 180-181.

${ }^{2}$ MONEREO PÉREZ, J. L. y ORTEGA LOZANO, P. G.: El derecho de huelga: configuración y régimen jurídico, Cizur Menor (Navarra), Aranzadi, 2019, p. 13.

${ }^{3}$ MONEREO PÉREZ, J. L.: "Derecho de negociación y acción colectiva (art. 28)", en MONEREO ATIENZA, C. y MONEREO PÉREZ, J. L. (Dirs. y coords.) et al: La Europa de los derechos: estudio ISSN: 2174-6419 Lex Social, vol. 11, núm. 2 (2021)
} 
manifestarse en multitud de formas, que analíticamente pueden reflejar un conflicto organizado (normalmente sindical) o un conflicto no organizado (o espontáneo). Pero que la huelga sea la forma de expresión principal de conflicto industrial no supone que se confunda con él, ni siquiera que a través de ella se localice la presencia de todos los conflictos; la huelga no agota las distintas y variadas formas de expresión del conflicto. Ello es tan evidente como el hecho de que la ausencia de huelgas no significa necesariamente la ausencia ni de conflicto ni de otras formas exteriorizadas de expresión del mismo ${ }^{4}$. El dato deberá retenerse porque las limitaciones a la acción huelguística pueden traducirse al tiempo en formas "desviantes" de manifestación de la conflictividad, ante el comprobado fenómeno histórico del alto grado de sustituibilidad entre las mismas.

En sus distintas formas de expresión el fenómeno de la huelga viene a situarse entre la protesta empresarial y la más amplia expresión del descontento social, siendo la lógica de la acción directa muy distinta según las variables del contexto institucional y de relaciones industriales en que se desarrolle. Esto quiere decir que metodológicamente se deberá de estar a las características del contexto institucional y a la misma tradición sindical que enmarca el conflicto en el plano de cada formación social ${ }^{5}$. Ello pone de relieve que la fenomenología de la huelga depende de un complejo de condiciones (sociales, económicas y políticas) en las que se origina el conflicto: el desenvolvimiento vital del hecho huelguístico está en función del modo de vivir de una comunidad, que no sólo

sistemático de la carta de los derechos fundamentales de la Unión Europea, Granada, Comares, 2012, p. 659. Georges Lefranc afirmaba que "la huelga es algo distinto de una brusca irrupción de la violencia en las relaciones laborales. Puede ser la sonda que, rompiendo un comportamiento estanco, establezca nuevos contactos con la realidad; tanto económica, obrera como sindical. En el mundo que los poderes públicos, los tecnócratas, los dirigentes de empresas y los dirigentes sindicales intentan organizar, cada uno a su manera, la huelga sigue siendo un elemento de espontaneidad; traduce la rebeldía del hombre tal como él es, con sus cualidades y sus defectos, contra los esquemas y alienaciones de toda especie". Cfr. LEFRANC, G.: La huelga: historia y presente, Barcelona, Ed. Laia, 1972, pp. 222-223.

${ }^{4}$ MONEREO PÉREZ, J. L. y ORTEGA LOZANO, P. G.: "Servicios mínimos con ocasión del ejercicio del derecho de huelga", en AA. VV.: Jurisprudencia Constitucional sobre trabajo y Seguridad Social, Tomo XXXVI: (2015-2018), Cizur Menor (Navarra), Aranzadi, 2019, pp. 633 y ss. MONEREO PÉREZ, J. L. y ORTEGA LOZANO, P. G.: "Sustitución interna de trabajadores y utilización de medios técnicos no habituales en jornada de huelga", en AA. VV.: Jurisprudencia Constitucional sobre trabajo y Seguridad Social, Tomo XXXVI: (2015-2018), Cizur Menor (Navarra), Aranzadi, 2019, pp. 999 y ss. ORTEGA LOZANO, P. G. y GUINDO MORALES, S.: "Derecho de huelga y nuevas tecnologías: a propósito del esquirolaje interno y tecnológico", Nueva revista española de derecho del trabajo, núm. 225, 2019, pp. 77 y ss.

${ }^{5}$ Sobre estas variables incidentes en la dinámica del conflicto y sus formas de expresión y, en definitiva, sus factores de causación, véase el estudio específico y su indicación metodológica, de SOSKICE, D.: "Oleadas de huelgas y explosiones salariales, 1968-70: Interpretación económica”, en CROUCH, C. y PIZZORNO, A. (Coords.) et al: El resurgimiento del conflicto de clases en Europa occidental a partir de 1968. II. Análisis comparativo, trad. N. Sánchez Sainz-Trápaga, Madrid, Ministerio de Trabajo y Seguridad Social, Servicio de Publicaciones, 1991, pp. 311 y ss.; LEFRANC, G.: La huelga: historia y presente, Barcelona, Ed. Laia, 1972, passim. En una perspectiva más amplia sobre los mecanismos institucionales diseñados para la ordenación de los conflictos, véase GOLDTHORPE, J. H. (Comp.): Orden y conflicto en el capitalismo contemporáneo, trad. M. Fernández de Loaysa, Madrid, Ministerio de Trabajo y Seguridad Social, 1991, pp. 123 y ss. Respecto a la relación histórica del arma de la huelga y el poder sindical, véase BROWN, H. P.: Los orígenes del poder sindical, trad. A. Conde, Madrid, Ministerio de Trabajo y Seguridad Social, 1990, pp. 11 y ss., y pp. 121 y ss. 
"determina", sino que además contribuye a "definir" las relaciones entre los actores del sistema ${ }^{6}$.

Todos esos factores contextualizan el sistema de relaciones industriales, articulado según el modelo-tipo de las relaciones de carácter triangular, del que no se puede prescindir en el análisis de cualquiera de las instituciones laborales. La huelga no es una excepción, tanto más si se repara en que la misma constituye un "medio" utilizable por los trabajadores por cuenta ajena con indiferencia de las continuas contingencias que motiven su uso. Es así, la huelga no constituye un simple elemento del funcionamiento del sistema de relaciones laborales, sino un presupuesto de la fundamentación del mismo: el sistema de relaciones laborales es la respuesta al conflicto industrial del que la huelga constituye la forma más evidente de expresión ${ }^{7}$.

La huelga es uno de los medios legítimos fundamentales de que disponen los trabajadores y sus organizaciones para la promoción y defensa de sus intereses económicos y sociales. En una perspectiva de conjunto se puede definir como una perturbación del proceso productivo concertada colectivamente como medida de presión para la defensa de intereses colectivos o generales de los trabajadores ${ }^{8}$. En efecto, la huelga es el arma más importante que detenta el movimiento obrero para la defensa de los intereses y valores que le son propios. La huelga es un contrapeso que tiene por objeto permitir que las personas en estado de dependencia salarial establezcan una nueva relación de fuerzas en un sentido más favorable para ellas; en definitiva, tiende a restablecer el equilibrio entre partes de fuerza económica desigual ${ }^{9}$. El derecho a huelga es el derecho reconocido a una de las partes del contrato de trabajo a incumplir sus obligaciones contractuales sin que ello, en contra de los principios inspiradores del sistema contractual, pueda generar ningún tipo de perjuicio en sus relaciones contractuales ${ }^{10}$.

Lo que modula históricamente las formas de acción directa, la función y los objetivos perseguibles mediante la huelga, y especialmente el tratamiento jurídico que la misma

\footnotetext{
${ }^{6}$ MONEREO PÉREZ, J. L.: "Prólogo: la huelga en el sistema de relaciones laborales", en MONEREO PÉREZ, J. L. (Coord.) et al: Derecho de huelga y conflictos colectivos. Estudio crítico de la doctrina jurídica, Granada, Comares, 2002, p. XVI.

${ }^{7}$ Cfr. NAPOLI, M.: “El marco jurídico-institucional", en CELLA, G. P. y TREU, T. (a cargo de): Las relaciones industriales en Italia, trad. A. Gimeno, Madrid, Ministerio de Trabajo y Seguridad Social, 1991, p. 423.

${ }^{8}$ MONEREO PÉREZ, J. L.: "Derecho de negociación y acción colectiva (art. 28)", en MONEREO ATIENZA, C. y MONEREO PÉREZ, J. L. (Dirs. y coords.) et al: La Europa de los derechos: estudio sistemático de la carta de los derechos fundamentales de la Unión Europea, Granada, Comares, 2012, p. 659. MONEREO PÉREZ, J. L.: "El modelo normativo de huelga en la jurisprudencia del Tribunal Constitucional", en CABEZA PEREIRO, J. y MARTÍNEZ GIRÓN, J. (Coords.) et al: El conflicto colectivo y la huelga. Estudios en homenaje al profesor Gonzalo Diéguez, Murcia, Laborum, 2008, p. 262.

9 MONEREO PÉREZ, J. L.: "Derecho de negociación y acción colectiva (art. 28)", en MONEREO ATIENZA, C. y MONEREO PÉREZ, J. L. (Dirs. y coords.) et al: La Europa de los derechos: estudio sistemático de la carta de los derechos fundamentales de la Unión Europea, Granada, Comares, 2012, p. 659.

${ }^{10}$ DURÁN LÓPEZ, F.: "Huelga y servicios esenciales", en Revista de administración sanitaria siglo XXI, vol. 8, núm. 1, 2010, p. 129.
} 
recibe (como delito, como libertad o como derecho; y hecha esta última "elección", si configurada como derecho fundamental del hombre o como mero derecho instrumental al servicio de la negociación colectiva) ${ }^{11}$. Esta confluencia de factores de orden diverso es lo que conforma modelos "reales" de huelga no fácilmente reductibles a su "encasillamiento" en modelos teóricos puros ${ }^{12}$. De cualquier modo, a pesar de su inexactitud (ante todo por su rigidez y alejamiento de la más compleja y rica experiencia cotidiana del derecho), tales modelos tienen la virtualidad de "condensar" algunos de los rasgos distintivos de los sistemas del derecho de huelga imperantes en los países de nuestra área geopolítica, y por ello facilita su análisis técnico, pero siempre que se acepte la premisa de su valor esencialmente relativo. Si se atiende a la conformación del sistema institucional de relaciones laborales sería posible individualizar dos modelos normativos de derecho de huelga ${ }^{13}$ : el modelo iusprivatista (que con distinto grado residencia la huelga en el ámbito restringido de las relaciones laborales y en defensa de intereses profesionales en sentido estricto, lo que provoca que la huelga sea un mero elemento auxiliar de la negociación colectiva) y el modelo dinámico o "sociopolítico" (que configura a la huelga como un medio para la autotutela de los intereses colectivos de los trabajadores en todos los ámbitos de la vida social, es decir, como un instrumento de emancipación social de la clase trabajadora y no exclusivamente un medio de presión en el marco de las relaciones laborales) ${ }^{14}$.

Desde el punto de vista jurídico-político ${ }^{15}$, esta "fisiología" funcional de la huelga se refleja (pero, recuérdese, que el derecho es tanto variable dependiente como factor determinante de la orientación social) en la configuración normativa del derecho de huelga: bien como uno de los derechos humanos (derecho fundamental de tipo social atribuido a todos los trabajadores individuales), o bien como un derecho sindical normalmente vinculado a la contratación colectiva (y, de ordinario, ello conduce a una concepción orgánica del derecho, en la medida que es reconocido como de exclusiva titularidad sindical) y utilizable como el último recurso de que disponen los trabajadores en las relaciones laborales (ligado a los conflictos que se suscitan en los centros de

\footnotetext{
${ }^{11}$ Vid. KAHN-FREUND, O.: "Il diritto di sciopero, la sua estensione e i suoi limiti", en RDL, núm. 4, 1978, pp. 378-379. KAHN-FREUND, O.: Trabajo y Derecho; estudio preliminar de J. Mª Galiana Moreno, edición al cuidado de J. L. Monereo Pérez, Granada, Comares (Colección Crítica del Derecho), 2019, pp. 409 y ss.

12 MONEREO PÉREZ, J. L. y TOMÁS JIMÉNEZ, N.: "Derecho a Huelga (artículo 6 de la Carta Social Europea)", en MONEREO ATIENZA, C. y MONEREO PÉREZ, J. L. (Dirs. y Coords.) et al: La garantía multinivel de los derechos fundamentales en el Consejo de Europa. El Convenio Europeo de Derechos Humanos y la Carta Social Europea, Granada, Comares, 2017, p. 534.

${ }^{13}$ MONEREO PÉREZ, J. L.: "La constitucionalidad de las huelgas sociopolíticas (a propósito de la STC 36/1993, de 8 de febrero)", en AA. VV.: Homenaje al profesor Juan García Abellán, Murcia, Universidad de Murcia, 1994, pp. 223 y ss.

${ }^{14}$ Vid. VIDA SORIA, J.: "Comentario al art. 28.2 de la Constitución Española”, en ALZAGA VILLAAMIL, O. (Dir.) et al: Comentarios a las Leyes Políticas. Constitución Española de 1978, tomo III, Madrid, Edersa, 1983, pp. 230 y 231. MARTIN VALVERDE, A.: "El derecho de huelga en la Constitución de 1978”, en RPS, núm. 121, 1979, pp. 227 y ss.

15 MONEREO PÉREZ, J. L.: "La constitucionalidad de las huelgas sociopolíticas (a propósito de la STC 36/1993, de 8 de febrero)", en AA. VV.: Homenaje al profesor Juan García Abellán, Murcia, Universidad de Murcia, 1994, p. 224.
} 
trabajo). Para sorpresa de muchos, la configuración del derecho de huelga como derecho humano fundamental (derecho subjetivo público de libertad) amplía los objetivos legítimamente perseguibles mediante la huelga, sin posibilidad coherente de excluir su dimensión sociopolítica tras ser elevado a rango de derecho fundamental; en cambio, su conformación como derecho sindical no siempre ha permitido garantizar esa funcionalidad.

Un apunte significativo al tratar de abordar el examen de la naturaleza del derecho de huelga nos lo encontramos en la siguiente afirmación (huelga que, por cierto, durante el régimen franquista era considerada como "delito de lesa patria"16): el derecho de huelga tiene carácter fundamental (art. 28.2 CE); sin embargo, el derecho al trabajo no pasa de ser un derecho constitucional, pero de contenido puramente programático (art. 35.1 CE) ${ }^{17}$. La huelga es un derecho de los trabajadores lo que no supone establecer, frente a anteriores normas prohibitivas del hecho huelguístico, un marco de libertad de huelga, sino que determinadas medidas de presión de los trabajadores frente a sus empleadores merecen decididamente toda la protección y tutela por parte del ordenamiento jurídico ${ }^{18}$.

Además, como medida de reacción ${ }^{19}$, la huelga puede desplegar una triple dimensión: laboral, en la medida en que es expresión del conflicto de trabajo; social, al manifestarse como medida de oposición frente a desequilibrios inherentes al sistema económico imperante; y política, llegando incluso a producirse la intervención del Estado ${ }^{20}$.

Realizada esta introducción sobre la huelga, el objeto de esta investigación es abordar, en estrictos términos jurídicos, las huelgas políticas ${ }^{21}$ (con mención expresa a la última de las sentencias dictada por el Tribunal Supremo), refiriéndonos también, aunque brevemente, a las huelgas de solidaridad o apoyo y a las huelgas novatorias, precisamente, partiendo del contenido del artículo 11 RDLRT que viene a establecer que la huelga es ilegal: a) Cuando se inicie o se sostenga por motivos políticos o con cualquier otra

\footnotetext{
${ }^{16}$ BAYLOS GRAU, A.: "Procedimientos de fijación de los servicios esenciales", en AA. VV.: Cuadernos de derecho judicial. El nuevo régimen jurídico de la huelga y el cierre patronal, Madrid, Consejo General del Poder Judicial, 1993, p. 81.

${ }^{17}$ LÓPEZ-FANDO RAINAUD, J. R.: "Ejercicio del derecho de huelga. Modalidades lícitas, ilícitas y abusivas", en AA. VV.: Cuadernos de derecho judicial. El nuevo régimen jurídico de la huelga y el cierre patronal, Madrid, Consejo General del Poder Judicial, 1993, p. 41.

18 PALOMEQUE LÓPEZ, M. C.: "La huelga y el derecho de huelga en el proyecto de ley orgánica de huelga (PLOH): una reflexión general", en AA. VV.: Cuadernos de derecho judicial. El nuevo régimen jurídico de la huelga y el cierre patronal, Madrid, Consejo General del Poder Judicial, 1993, p. 296.

${ }_{19}$ Para otras medidas de reacción con construcción doctrinal, vid. GUINDO MORALES, S.: Acción de impugnación judicial, calificación y efectos de la extinción del contrato de trabajo por circunstancias objetivas, Murcia, Laborum, 2020. GUINDO MORALES, S.: Caracterización jurídica y causas del despido objetivo en la normativa, doctrina y jurisprudencia tras las recientes reformas laborales, Granada, Comares, 2020.

${ }^{20}$ RAMOS QUINTANA, M. I.: “Conflicto de intereses, negociación colectiva y derecho de huelga: cambios en el sistema productivo y disrupción normativa”, en Revista de derecho social, núm. 83, 2018, p. 169.

${ }^{21}$ MONEREO PÉREZ, J. L. y ORTEGA LOZANO, P. G.: El derecho de huelga: configuración y régimen jurídico, Cizur Menor (Navarra), Aranzadi, 2019, pp. 261 y ss. 
finalidad ajena al interés profesional de los trabajadores afectados. b) Cuando sea de solidaridad o apoyo, salvo que afecte directamente al interés profesional de quienes la promuevan o sostengan. c) Cuando tenga por objeto alterar, dentro de su período de vigencia, lo pactado en un Convenio Colectivo o lo establecido por laudo. d) Cuando se produzca contraviniendo lo dispuesto en el presente Real Decreto-ley, o lo expresamente pactado en Convenio Colectivo para la solución de conflictos.

\section{MODALIDADES DE HUELGA EN ATENCIÓN A DIVERSOS CRITERIOS: ESPECIAL REFERENCIA AL CRITERIO TELEOLÓGICO. HUELGA LABORAL Y HUELGA POLÍTICO-SOCIAL}

La huelga es un fenómeno social multiforme en sus fines y en su modo de realización. Existe una íntima vinculación entre los tipos de huelga y el contenido esencial del derecho de huelga. Hasta tal punto es así que el derecho de huelga comprende la facultad de elegir la modalidad de huelga. Debe destacarse que a nivel normativo no existe, ni en la CE ni en el RDLRT, una clasificación global de las distintas modalidades de la huelga ${ }^{22}$. Por ello, la clasificación de las diversas modalidades de huelga ha de atender, de forma principal, al dato sociológico - de relevancia jurídica- del hecho de la huelga. En tal sentido puede atenderse a dos grandes criterios de ordenación tipológica de la huelga, con una relevancia desigual a efectos de su calificación jurídica, y a algún otro criterio residual. Veámoslos ${ }^{23}$ :

a) Un primer criterio hace referencia a los fines, objetivos o funciones de la huelga (criterio teleológico), pudiéndose, desde este punto de vista, distinguir entre huelga laboral (modelo iusprivatista) y huelga político-social (modelo publicista o sociopolítico $)^{24}$.

La primera modalidad, la huelga laboral, está orientada, en general, a conseguir una mejora de las condiciones de trabajo. La negociación colectiva constituye la referencia principal (no la única) de este tipo de huelga. La segunda modalidad general de huelga es la llamada político-social, que se caracteriza por expresar un rechazo o una reivindicación

\footnotetext{
${ }^{22}$ AA. VV.: "Modalidades de ejercicio del derecho de huelga. Cierre patronal", en MONEREO PÉREZ. J. L. (Coord.) et al: Derecho de huelga y conflictos colectivos. Estudio crítico de la doctrina jurídica, Granada, Comares 2002, p. 140.

${ }^{23}$ MONEREO PÉREZ, J. L. y ORTEGA LOZANO, P. G.: El derecho de huelga: configuración y régimen jurídico, Cizur Menor (Navarra), Aranzadi, 2019, pp. 245 y ss. MONEREO PÉREZ, J. L.: "Derecho de negociación y acción colectiva (art. 28)", en MONEREO ATIENZA, C. (Dir. y coord.) y MONEREO PÉREZ, J. L. (Dir. y coord.) et al: La Europa de los derechos: estudio sistemático de la carta de los derechos fundamentales de la Unión Europea, Granada, Comares, 2012, pp. 665 y 666.

${ }^{24}$ MONEREO PÉREZ, J. L.: "La constitucionalidad de las huelgas sociopolíticas (a propósito de la STC 36/1993, de 8 de febrero)", en AA. VV.: Homenaje al profesor Juan García Abellán, Murcia, Universidad de Murcia, 1994, pp. 221 y ss. AA. VV.: "Modalidades de ejercicio del derecho de huelga. Cierre patronal", en MONEREO PÉREZ. J. L. (Coord.) et al: Derecho de huelga y conflictos colectivos. Estudio crítico de la doctrina jurídica, Granada, Comares 2002, p.129.
} 
en relación a contenidos más generales - no necesariamente inherentes a la relación jurídica con el empresario-desconectados del proceso de negociación, o sobre los cuales, al menos, no se exige una negociación inmediata. Los intereses defendidos en la huelga no tienen por qué ser los intereses concretos y propios de los huelguistas, sino que pueden estar referidos en general a los trabajadores en cuanto tales. Normalmente, estas huelgas, que se definen de manera amplia como "políticas", se declaran como reacción o en señal de protesta por las políticas gubernamentales o públicas, generales o específicas, relativas, por ejemplo, a la seguridad social, a la reforma del mercado de trabajo, a la privatización o a la reestructuración de servicios públicos.

Respecto a la respuesta de la normativa internacional ante una huelga política, es preciso tener en cuenta que el Comité de Libertad Sindical y la Comisión de Expertos de la OIT han recurrido, en primer lugar, al art. 10 del Convenio de la OIT sobre la libertad sindical y la protección del derecho de sindicación, 1948, núm. 87, para la determinación de los objetivos que inspiran los derechos sindicales. En este sentido, el art. 10 define para los fines del Convenio lo que entiende por organización de trabajadores, estableciendo que es aquella "que tenga por objeto fomentar y defender los intereses de los trabajadores", trazando así una frontera hasta la que son aplicables los derechos y garantías reconocidos en el Convenio, que son de esta manera protegidos en la medida que realizan o tienden a realizar los objetivos mencionados, acogiendo no obstante un concepto amplio de los mismos y observándose que desde la OIT se ha rechazado de forma contundente la tesis de que el derecho de huelga debería limitarse a los conflictos de trabajo susceptibles de finalizar en un convenio colectivo. Por tanto, puede comprobarse lo decisivo que resulta la determinación de qué se entiende por "los intereses de los trabajadores", prevaleciendo la consideración de que los intereses tutelados por la huelga abarcan todos aquellos aspectos en los que de manera real y efectiva se vacía la situación de los trabajadores en su doble y estrecha condición de partes de una relación interprivada y miembros de uno de los grupos sociales en los que se estructura una sociedad pluralista ${ }^{25}$. Desde esta perspectiva, según la doctrina de la OIT, y de forma esquemática, las reivindicaciones que se defienden con la huelga pueden sintetizarse en tres categorías: las de naturaleza laboral (que buscan garantizar o mejorar las condiciones de trabajo y de vida de los trabajadores), las de naturaleza sindical (que persiguen garantizar y desarrollar los derechos de las organizaciones sindicales y de sus dirigentes) y las de naturaleza política $^{26}$. Si bien no se plantea por la OIT ninguna duda sobre la legitimidad de las dos primeras modalidades de huelga, respecto a las huelgas políticas sí que ha sido necesario que se pronunciase detenidamente. A partir de la referida delimitación del art. 10 del Convenio OIT núm. 87, el Comité de Libertad Sindical ha considerado que las huelgas de carácter puramente político no caen dentro del ámbito de los principios de la libertad

\footnotetext{
${ }^{25}$ VIDA SORIA, J. y GALLEGO MORALES, Á.: “Art. 28. Derechos sindicales y de huelga”, en ALZAGA VILLAAMIL, O. (Dir.) et al: Comentarios a la Constitución Española de 1978, tomo III (Arts. 24 a 38), Madrid, Edersa, 1996, pp. 273 y ss.

${ }^{26}$ GERNIGON, B., ODERO, A. y GUIDO, H.: Principios de la OIT sobre el derecho de huelga, Ginebra, Oficina Internacional de Trabajo, 2000, pp. 13 y ss. 
sindical, matizando no obstante el propio Comité que los intereses profesionales y económicos que los trabajadores defienden mediante el derecho de huelga abarcan la obtención de mejores condiciones de trabajo o las reivindicaciones colectivas de orden profesional, pero que también comprenden la búsqueda de soluciones a las cuestiones de política económica y social; y que, por tanto, los trabajadores y sus organizaciones deben poder manifestar su descontento sobre cuestiones económicas y sociales que guarden relación con los intereses de los trabajadores, en un ámbito más amplio que el de los conflictos de trabajo susceptibles de finalizar con un convenio colectivo determinado, siempre y cuando no perturben la tranquilidad pública. La conclusión práctica que se extrae de la doctrina de la OIT es que no puede declararse como ilegal una huelga nacional en protesta por las consecuencias sociales y laborales de la política económica del gobierno, incurriéndose si se prohíbe en una grave violación de la libertad sindical; conclusión extrapolable a las huelgas generales que sin duda poseen notables connotaciones políticas ${ }^{27}$.

Asimismo, la OIT ha establecido que cuando se trate de huelgas de carácter mixto, es decir, que confluyan algunas reivindicaciones de carácter laboral o sindical y otras de carácter sociopolítico, debe tenderse a reconocer la legitimidad de la huelga si la expresión de las reivindicaciones laborales o sindicales no aparece como un simple pretexto o simulación para encubrir en realidad objetivos puramente políticos desconectados de la promoción y defensa de los intereses de los trabajadores; ya que en el caso de que las huelgas sean de naturaleza puramente política no estarán cubiertas por los principios de libertad sindical. Todo ello sin desconocerse por la OIT que a veces no es fácil delimitar en la práctica los aspectos políticos de los aspectos profesionales de una huelga, ya que en la praxis de las relaciones conflictivas no hay intencionalidades puras sino mixtas y se interrelacionan intereses de carácter diverso casi imposibles de separar. Las políticas adoptadas por un gobierno repercuten frecuentemente de forma inmediata en los trabajadores o los empleadores, como sucede, por ejemplo, en caso de una congelación general de los precios y los salarios; habiendo concluido la Comisión de Expertos que las organizaciones encargadas de defender los intereses socioeconómicos y profesionales de los trabajadores deben, en principio, poder recurrir a la huelga para apoyar sus posiciones en la búsqueda de soluciones a los problemas derivados de las grandes cuestiones de política económica y social que tienen consecuencias inmediatas para sus miembros y para los trabajadores en general, especialmente en materia de empleo, de protección social y de nivel de vida. Entiende incluso el Comité de Libertad Sindical de la OIT que los empleadores, al igual que los trabajadores, también deberían

${ }^{27}$ MONEREO PÉREZ, J. L. y TOMÁS JIMÉNEZ, N.: "Derecho de Huelga (Art. 8.d PIDESC)", en MONEREO ATIENZA, C. y MONEREO PÉREZ, J. L. (Dirs. y Coords.) et al: El sistema universal de los derechos humanos. Estudio sistemático de la declaración universal de los derechos humanos, el pacto internacional de derechos civiles y políticos, el paco internacional de derechos económicos, sociales y culturales y textos internacionales concordantes, Granada, Comares, 2014, p. 927. 
tener la posibilidad de recurrir a huelgas (o acciones de protesta) en relación con la política económica y social de los gobiernos ${ }^{28}$.

No obstante, la OIT también ha señalado límites a las huelgas sociopolíticas en el sentido de que es legítima la prohibición de las mismas respecto a los funcionarios públicos, que ejercen funciones de autoridad en nombre del Estado o con respecto a los trabajadores de los servicios esenciales en el sentido estricto del término (es decir, aquellos servicios cuya interrupción podría poner en peligro la vida, la seguridad o la salud de la persona en toda o parte de la población). Al hilo de lo anterior, el comité de Libertad Sindical de la OIT distingue entre la "huelga política pura", que sería aquella dirigida contra la política del Gobierno sin que su objeto sea un conflicto de trabajo, y la "huelga de imposición económico-política" (o huelga política con trascendencia laboral), que sería la adoptada contra la política del Gobierno referida a la adopción de medidas relacionadas con las relaciones de trabajo. Estas últimas son consideradas lícitas por este organismo que las considera garantizadas por los Convenios de la OIT $^{29}$.

Por otro lado, en el ámbito de la Unión Europea, la CDFUE reconoce el derecho fundamental a la huelga en el art. 28 pero no define, ni describe tal derecho, ni sus contenidos esenciales que lo hacen reconocible como tal. En vez de ello, remite a las legislaciones y prácticas de los Estados miembros que determinen la regulación de las modalidades y condiciones de ejercicio del derecho siendo necesario encauzar el ejercicio de este derecho a través de estas legislaciones nacionales, que a su vez deberán respetar los límites derivados de las normas internacionales y europeas reguladoras de este derecho social fundamental de libertad. En este sentido, recuérdese que en el sistema de los Tratados (art. 153.5 TFUE), el derecho de huelga está excluido del ámbito de competencias de la Unión Europea, lo que debilita la tutela comunitaria de este derecho fundamental, e impide que la legislación comunitaria pueda no sólo garantizar satisfactoriamente este derecho, sino también realizar una función promocional eficaz.

Atendiendo a los fines $\mathrm{u}$ objetivos perseguibles (criterio teleológico), poseen una particular dificultad las llamadas "huelgas novatorias" (cuando tengan por objeto alterar, dentro de su período de vigencia, lo pactado en un convenio colectivo o lo establecido por laudo arbitral). El art. 28 CDFUE hace referencia a huelgas "en caso de conflictos de intereses". De este modo no quedaría expresamente amparada en la garantía ex art. 28 CDFUE las huelgas llamadas novatorias, esto es, modificativas de lo pactado colectivamente o de lo fijado en laudo arbitral de obligado cumplimiento. Pero que no se encuentren en la esfera de la garantía formulada en la Carta, no supone la prohibición absoluta de este tipo de huelgas (ya en sí discutible desde la lógica de la huelga como arma de defensa de los intereses de los trabajadores, con independencia de que se encuentren o no "juridificados"). Al hilo de lo anterior, en las legislaciones de los Estados

\footnotetext{
${ }^{28}$ Caso núm. 2530 (Uruguay), 348. ${ }^{\circ}$ informe, párr. 1190.

${ }^{29}$ MONEREO PÉREZ, J. L. y ORTEGA LOZANO, P. G.: El derecho de huelga: configuración y régimen jurídico, Cizur Menor (Navarra), Aranzadi, 2019, pp. 248 y ss. 
miembros suele establecerse una prohibición limitada, porque suele realizarse una interpretación restrictiva de la huelga novatoria, señalando lo siguiente: a) Admitiendo la posibilidad de ejercitar la huelga durante la vigencia de un convenio colectivo cuando la finalidad de la huelga no sea estrictamente la de alterar el convenio, como puede ser reclamar una interpretación del mismo o exigir reivindicaciones que no impliquen modificación de convenio (huelga por causa de conflictos jurídicos); b) Entendiendo que es posible reclamar una alteración del convenio en aquellos casos en que éste haya sido incumplido por la parte empresarial o se haya producido un cambio absoluto y radical de las circunstancias que permitan aplicar la llamada cláusula rebus sic stantibus. Con todo, quedan sentadas dos cuestiones principales: la primera, que es legítima consideración legal de un deber de paz implícito al convenio colectivo durante el período de vigencia, y hasta el momento en que pueda ser denunciado; $y$, segunda, que existen varios supuestos donde la huelga es legítima a pesar de la vigencia de un convenio colectivo, de manera que huelga y convenio colectivo no se repelen necesariamente.

La doctrina mayoritaria ha considerado que en el art. 11.c) RDLRT se impone un deber legal de paz relativo, con eficacia subjetiva general ${ }^{30}$, en virtud del cual se prohíbe la realización de huelgas novatorias ${ }^{31}$, sin que se requiera cláusula convencional expresa en el convenio ${ }^{32}$. Este deber impone no hacer recurso a la huelga para modificar lo pactado en convenio colectivo durante su período de vigencia.

\footnotetext{
${ }^{30}$ Es decir, quedarían vinculados todos los trabajadores incluidos en la unidad de negociación o ámbito de aplicación del convenio.

${ }^{31}$ SEMPERE NAVARRO, A. V.: "Suspensión cautelar de huelga novatoria (el conflicto futbolístico)", en Nueva Revista Española de Derecho del Trabajo, núm. 176, 2015, pp. 17 y ss.

${ }^{32}$ Vid. MORENO VIDA, Ma . N.: "Sobre la mediación extrajudicial previa como presupuesto de validez de la huelga y la ilegalidad de las huelgas novatorias", en Aranzadi Social: Revista Doctrinal, núm. 12, 2008, pp. 31 y ss. VALDÉS DAL-RÉ, F.: "Límites al derecho de huelga: apuntes críticos", en Cuadernos de Derecho del Trabajo, núm. 3, 1977, pp. 25 y ss. SALA FRANCO, T. y ALBIOL MONTESINOS, I.: Derecho Sindical, Valencia, Tirant lo Blanch, 1991, p. 454; MATIA PRIM, J., SALA FRANCO, T., VALDÉS DALRÉ, F. y VIDA SORIA, J.: Huelga, cierre patronal y conflictos colectivos, Madrid, Civitas, 1982, pp. 86 y ss. GARCIA BLASCO, J.: El derecho de huelga en España: calificación y efectos jurídicos, Barcelona, Bosch, 1983, pp. 309 y ss. ALONSO OLEA, M. y CASAS BAAMONDE, Mª E.: Derecho del Trabajo, Madrid, Civitas, pp. 906-908. BARREIRO GONZÁLEZ, G.: "Ensayo crítico sobre la paz laboral en el convenio colectivo con especial referencia a su carácter inmanente", en REDT, núm. 4, 1980. GOÑI SEIN, J. L.: "La responsabilidad civil del sindicato por huelga", en REDT, núm. 43, 1990, p. 438. SALA FRANCO, T.: “Comentario al art. 82 ET”, en AA.VV.: El Estatuto de los Trabajadores, Madrid, 1981, pp. 552 y 553. DEL REY GUANTER, S.: Negociación colectiva y paz laboral, Madrid, Instituto de Estudios Laborales, 1984, pp. 123 y ss. y 324 y ss. DE LA VILLA GIL, L. E., GARCIA BECEDAS, G. y GARCIA PERROTE ESCARTIN, I.: Instituciones de Derecho del Trabajo, Madrid, Ceura, 1991, pp. 253 y ss. Una síntesis sobre las diversas posiciones doctrinales sobre la existencia del deber de paz inmanente al convenio, en ALONSO OLEA, M. y CASAS BAAMONDE, Mª. E.: Derecho del Trabajo, Madrid, Civitas, pp. 906-908. GARCÍA FERNÁNDEZ, M.: Manual de Derecho del Trabajo, Barcelona, Ariel, 1990, p. 226. GARCIA BLASCO, J.: El derecho de huelga en España: calificación y efectos jurídicos, Barcelona, Bosch, 1983, pp. 309-329. BAYLOS GRAU, A.: Derecho de huelga y servicios esenciales, Madrid, Tecnos, 1988, $2^{\mathrm{a}}$ ed., pp. 237 y ss.

Sin embargo, la STC 11/1981, de 8 de abril [RTC 1981\11] vino a consagrar la legitimidad constitucional de las cláusulas de paz y la muy matizada ilegalidad de las denominadas "huelgas novatorias" (o modificativas de convenios). De este modo entre los dos polos en tensión paz laboral-huelga, se ha primado la paz laboral como elemento de estabilización del sistema de negociación colectiva y, sólo subordinadamente, como mecanismo para la gestión sindical de la huelga.
} 
Esta declaración de constitucionalidad del art. 11.c) RDLRT y, por consiguiente, la inmanencia (por mandato legal) al convenio de un deber legal de paz relativo ${ }^{33}$, exige interpretar el art. 82.2 $\mathrm{ET}^{34}$ como posibilidad legal de que las partes negociadoras puedan pactar un deber de paz absoluto y las reglas para la composición de los conflictos suscitados durante la vigencia del convenio ${ }^{35}$.

De este modo serían formalmente congruentes los arts. 82.2 LET y el art. 8.1 RDLRT. Este último prevé el pacto ("los Convenios Colectivos podrán establecer"36) de un deber de paz absoluto, esto es, "la renuncia" al ejercicio del derecho de huelga durante la vigencia del convenio colectivo ${ }^{37}$.

Es más que dudoso que la expresión "fuerza vinculante de los convenios", ex art. $37.1 \mathrm{CE}$, pueda ser interpretada como la garantía constitucional de un deber de paz inmanente a todo convenio colectivo, porque esta disposición lo que se limita a consagrar es que la autonomía colectiva es fuente del derecho y que los convenios colectivos son derecho objetivo. Por otra parte, entender que el art. 37.1 CE consagra un deber de paz inmanente a todo tipo de convenio, supondría también extender ese deber de paz a los convenios colectivos extraestatutarios, planteando problemas de difícil solución que van más allá de los aquí globalmente considerados. Se ha advertido, en este orden de ideas, que el "reconocimiento constitucional del derecho de huelga actúa en contra de un deber de paz inmanente, ni absoluto (prohibitivo de cualquier medida de presión) ni relativo (prohibitivo sólo de las dirigidas contra lo estipulado en el acuerdo colectivo de trabajo)". Cfr. OJEDA AVILÉS, A.: Derecho Sindical, Madrid, Tecnos, 1990, $5^{\circ}$ edición, p. 612.

Es clarificador en parte el debate parlamentario del art. 37 CE, véase, por todos, VIDA SORIA, J.: "Génesis de las normas laborales en la Constitución Española de 1978", en AA. VV.: Estudios de Derecho del Trabajo en memoria del profesor Gaspar Bayón Chacón, Madrid, Civitas, 1980, pp. 255 y ss. Vid. SERRANO MARTÍNEZ, J. E.: "Titularidad y ejercicio del derecho de huelga: el papel de sindicato", en AA. VV.: Jurisprudencia constitucional y relaciones laborales, Madrid, Centro de Estudios Constitucionales, 1983, p. 180. Sobre la calificación de huelga ilegal por tener por objeto alterar el convenio durante su vigencia, véase GIL y GIL, J. L.: "Ilegalidad e incumplimiento de servicios mínimos en la huelga", en REDT, núm. 39, 1989, pp. 507 y ss. Interesante también MONEREO PÉREZ, J. L. y ORTEGA LOZANO, P. G.: "Servicios mínimos con ocasión del ejercicio del derecho de huelga", en AA. VV.: Jurisprudencia Constitucional sobre trabajo y Seguridad Social, Tomo XXXVI: (2015-2018), Cizur Menor (Navarra), Aranzadi, 2019, pp. 633 y ss. MONEREO PÉREZ, J. L. y ORTEGA LOZANO, P. G.: "Sustitución interna de trabajadores y utilización de medios técnicos no habituales en jornada de huelga", en AA. VV.: Jurisprudencia Constitucional sobre trabajo y Seguridad Social, Tomo XXXVI: (2015-2018), Cizur Menor (Navarra), Aranzadi, 2019, pp. 999 y ss. ORTEGA LOZANO, P. G. y GUINDO MORALES, S.: "Derecho de huelga y nuevas tecnologías: a propósito del esquirolaje interno y tecnológico", Nueva revista española de derecho del trabajo, núm. 225, 2019, pp. 77 y ss.

${ }^{33}$ Carácter relativo del deber legal de paz que confirma la STC 38/1990, de 1 de marzo, fj. 3 [RTC 1990138]. En ella se considera lícita la huelga promovida respecto a materias que no han sido objeto del convenio colectivo.

34 "Mediante los convenios colectivos y en su ámbito correspondiente, los trabajadores y empresarios regulan las condiciones de trabajo y de productividad; igualmente podrán regular la paz laboral a través de las obligaciones que se pacten".

${ }^{35}$ Vid. ALONSO OLEA, M. y CASAS BAAMONDE, Ma. E.: Derecho del Trabajo, Madrid, Civitas, pp. 811-815. SALA FRANCO, T. y ALBIOL MONTESINOS, I.: Derecho Sindical, Valencia, Tirant lo Blanch, 1991, p. 454. También incidiendo sobre la distinción entre deber legal de paz "relativo" y deber de paz "absoluto", véase MONTOYA MELGAR, A.: Derecho del Trabajo, Madrid, Tecnos, 1992, 13ª ed, p. 713.

${ }^{36}$ Para mayor abundamiento, vid. JURADO SEGOVIA, Á.: "Negociación colectiva y derecho de huelga", en PÉREZ DE LOS COBOS ORIHUEL, F. (Dir.) y MONREAL BRINGSVAERD, E. (Coord.) et al: Real Decreto-Ley 17/1977, de 4 de marzo, sobre relaciones de trabajo (Régimen legal y jurisprudencial de la huelga, el cierre patronal y el conflicto colectivo), Madrid, La Ley, 2014, pp. 667 y ss.

${ }^{37}$ En realidad, disponibilidad vía transacción y compromiso del ejercicio del derecho de huelga; de las facultades de ejercicio colectivo del derecho más exactamente. El Tribunal Constitucional ha procedido al esclarecimiento del art. 8.1 RDLRT mediante una interpretación de autoridad. Según el Tribunal ISSN: 2174-6419 Lex Social, vol. 11, núm. 2 (2021) 
En suma, en los pactos de paz o de tregua sindical no queda afectada la esfera de titularidad individual de cada trabajador. La cláusula de paz negociada comporta la obligación del sindicato firmante de no proclamar la huelga con objeto de modificar antes del término de su vigencia el convenio colectivo pactado. Es así que el sindicato está legitimado para disponer, en sede negocial, de sus propias facultades de ejercicio colectivo de la huelga ${ }^{38}$.

Se ha de reparar en que desde la STC 11/1981, de 8 de abril ${ }^{39}$, es admisible la huelga hecha con la finalidad de exigir modificaciones que no impliquen alteración del convenio colectivo. El Alto Tribunal no considera al convenio como un conjunto estático que agote la totalidad de los intereses en juego susceptibles de confrontación durante su periodo de vigencia $^{40}$. Implícitamente este es el criterio también deducible de la STC 38/1990, de 1 de marzo ${ }^{41}$. En esta sentencia el problema se suscita en la relación entre huelga y convenio colectivo ordinario o "extraestatutario". En efecto, esta sentencia acepta la legitimidad de una huelga para reivindicar materias no incluidas en el convenio colectivo vigente: la huelga no suponía la ruptura de una tregua tácitamente convenida, ni buscaba la alteración del convenio colectivo vigente en la empresa, ya que se trataba de un aspecto de la relación de trabajo que venía regulado por otras fuentes ${ }^{42}$. En relación al supuesto de

Constitucional "por regla general puede hacerse por representante aquello que uno puede hacer por sí mismo. Si los derechos son renunciables, la dificultad no está en la representación, sino en el carácter especial o especialísima que ésta deba tener. La anterior disquisición es, sin embargo, innecesaria. Por mucho que el apartado 1 del articulo 8 hable de "renuncia", es claro que no estamos en presencia de una genuina renuncia. $Y$ ello por dos tipos de razones: porque la renuncia es siempre un acto definitivo e irrevocable y la llamada "renuncia" del apartado 1 del art. 8 es sólo temporal y transitoria (durante la vigencia del convenio) y no afecta al derecho en sí mismo, sino sólo a su ejercicio, de manera que no hay extinción del derecho, sino compromiso de no ejercitarlo, que entraña una pura obligación, que puede incumplirse arrastrando las consecuencias del incumplimiento. Cuando el compromiso de no ejercitar el derecho se establece obteniendo a cambio determinadas compensaciones, no se puede decir que un pacto como éste, que es un pacto de paz. laboral, sea ilícito y menos aún contrario a la Constitución" (STC 11/1981, de 8 de abril, fj. 14 [RTC 1981\11]).

${ }^{38}$ MONEREO PÉREZ, J. L.: "La huelga (artículo 28.2 CE)", en AA. VV.: Comentario a la Constitución Socio-Económica de España, Granada, Comares, 2002, p. 1085.

${ }^{39}$ STC 11/1981, de 8 de abril [RTC 1981\11].

${ }^{40}$ Véase, en este sentido, ALONSO OLEA, M. y CASAS BAAMONDE, M ${ }^{\text {a }}$ E.: Derecho del Trabajo, Madrid, Civitas, p. 814. SALA FRANCO, T. y ALBIOL MONTESINOS, I.: Derecho Sindical, Valencia, Tirant lo Blanch, 1991, p. 455.

${ }^{41}$ STC 38/1990, de 1 de marzo [RTC 1990138]. Un breve comentario a esta sentencia en MERCADO NEUMANN, S.: "Huelga y convenio colectivo impropio", en REDT, núm. 50, 1991, pp. 985 y ss.

${ }^{42}$ Según esta STC 38/1990, de 1 de marzo [RTC 1990138]: la huelga convocada en el caso, no suponía la ruptura de una tregua expresa o tácitamente convenida con la empresa, sino que la convocatoria de huelga pretendía únicamente que la dirección de la empresa accediese a la petición de negociaciones que los trabajadores le habían transmitido previamente, con el fin de dialogar o tratar sobre una eventual revisión del plus de nocturnidad que se venía aplicando, lo que pone de manifiesto que la huelga que motivó la sanción de suspensión de empleo y sueldo no encaja en el supuesto previsto en el art. 11.d) RDLRT, por el que se califica de ilegal la huelga que tenga por objeto alterar dentro de su periodo de vigencia, lo pactado en convenio colectivo o lo establecido por laudo, por lo que en el caso en que no se buscara la alteración del convenio colectivo vigente en la empresa, puesto que se trataba de un aspecto de la relación de trabajo que venía regulado por otras fuentes, tampoco se pretendía adelantar la fecha de término del acuerdo o pacto alguno, puesto que no consta que el sistema de retribución del trabajo nocturno establecido en la empresa tuviera una duración predeterminada o, menos aún, que ese plazo no hubiera concluido, se llega, en consecuencia, a la conclusión de que la sanción impuesta por la empresa no estaba justificada, puesto que los trabajadores se ISSN: 2174-6419 Lex Social, vol. 11, núm. 2 (2021) 
hecho de esta sentencia del Tribunal Constitucional, es pertinente puntualizar que el deber de paz relativo impuesto ex art. 11.c) RDLRT (es decir, la prohibición de acudir a medidas de acción directa para alterar lo pactado en un convenio colectivo en vigor) no entra en juego respecto de los convenios colectivos "extraestatutarios" -en el estadio actual del derecho positivo, para los cuales no se establece en normativa legal alguna, y no se pudiese deducir de todo convenio colectivo, porque un tal deber de paz inmanente al convenio por el hecho de serlo no tiene acogida en el art. 37.1 CE-. Ello supone la admisibilidad de las huelgas novatorias que afecten a convenios colectivos extraestatutarios. El Tribunal Constitucional ha entrado indirectamente en el tema, indicando que es lícita la huelga cuando no se dirige contra el convenio colectivo vigente en la empresa y se sostiene sobre materias no reguladas por aquél, sino por otras fuentes de aplicación en la empresa ${ }^{43}$. Entrando ya de forma directa a resolver sobre esta materia, cabe apreciar la existencia de una doctrina jurisprudencial bastante consolidada en el sentido de afirmar que no cabe equiparar lisa y llanamente el acuerdo extraestatutario a los convenios colectivos regulados en el sistema del Estatuto de los Trabajadores. Por otra parte, la jurisprudencia hace una interpretación muy restrictiva de la prohibición de celebrar huelgas sobre temas pactados en convenio colectivo, pues el orden normativo paccionado no constituye un ordenamiento cerrado, sino que pueden mantenerse negociaciones y conflictos abiertos.

A diferencia de la llamada "huelga novatoria" (que versan en términos de principio sobre conflictos de intereses colectivos, por lo que se pretende alterar los términos de composición del conflicto ya regulado por un convenio colectivo vigente), la huelga "motivada por conflictos jurídicos" no plantea (en un plano jurídico-formal, al menos) la alteración de lo pactado en acuerdos colectivos, sino una controversia suscitada por una determinada interpretación de un convenio o acuerdo colectivo vigente. Sin embargo, en la práctica los conflictos sobre intereses y los conflictos jurídicos pueden llegar a entremezclarse e incluso confundirse, ya que muchos conflictos jurídicos no serán tanto de aplicación o interpretación de una norma preexistente como la expresión "encubierta" bajo un tamiz interpretativo del sentido de las normas vigentes de un verdadero conflicto de intereses que pretende la alteración de lo establecido en normas de origen profesional.

Aunque no es el único criterio clasificatorio en función de los fines, tiene la indudable ventaja de que permite conectar de forma automática con el aspecto relativo a su calificación jurídica.

b) Un segundo criterio clasificador hace referencia a la forma de realizar la huelga, y, más concretamente, por la actividad que se desarrolle, o se deje de desarrollar, en relación con la prestación laboral. Dicho criterio permite diferenciar entre un concepto estricto de huelga (o, mejor, restrictivo), entendida como cesación del trabajo, y un

encontraban dentro de lo que puede entenderse como ejercicio lícito del derecho de huelga.

${ }^{43}$ STC 38/1990, de 1 de marzo, fj. 1 [RTC 1990\38]

ISSN: $2174-6419$

Lex Social, vol. 11, núm. 2 (2021) 
concepto estricto amplio, que incluya también otras formas de perturbación o alteración del desarrollo normal del trabajo.

c) Igualmente, de la toma en consideración de otros criterios, surgen nuevas clasificaciones. Así, en función de la duración prevista, la huelga puede ser indefinida, por tiempo determinado, de carácter intermitente o continuado -etcétera- ${ }^{44}$. Según si el conflicto afecta o no directamente a los trabajadores huelguistas, se puede distinguir entre huelga primaria y huelga de apoyo o solidaridad. Existen también distintos tipos de huelga dependiendo del ámbito personal de trabajadores convocados (huelga total -si afecta a toda la plantilla-, rotatoria -turnándose distintos grupos de huelguistas-, neurálgica referida a puestos de trabajo clave para el funcionamiento de la empresa-, en general todos los sectores productivos-, etcétera), o de los sujetos convocantes (huelga de trabajadores, huelga de funcionarios, huelga sindical, huelga autoconvocada, etcétera).

Respecto a la huelga de solidaridad o apoyo, conviene tener presente que la solidaridad es uno de los principios básicos del movimiento obrero, cuya negación supondría negar también el mismo hecho sindical. Se trata, así, de un tema que incide en la propia esencia del sindicalismo en la medida en que éste solo existe cuando los trabajadores toman conciencia de la común pertenencia a una clase social que participa de un interés colectivo general y fines propios y se une para el logro de todos esos fines o de parte de ellos ${ }^{45}$.

El art. 11.b) RDLRT consideró ilegales ${ }^{46}$, sin más, a la huelga "cuando sea de solidaridad o apoyo, salvo que afecte directamente al interés profesional de quienes la promuevan o sostengan". Después de la declaración de inconstitucionalidad de la expresión "directamente" 47 se puede decir que en nuestro sistema jurídico vienen a ser legitimas en la práctica todas las huelgas de solidaridad, que son aquellas en las que el interés tutelado no es directamente deducible del vínculo profesional del trabajador huelguista ${ }^{48}$. Después de esta primera aproximación al tema por parte del Tribunal Constitucional se puede decir que la supresión del término "directamente" supone virtualmente la legitimidad de

\footnotetext{
${ }^{44}$ MONEREO PÉREZ, J. L.: "Las modalidades de huelga: la normalización jurídica de las llamadas huelgas anómalas (I y II)”, en DL, núms. 41 y 42, 1993-1994, passim.

${ }^{45}$ Véase TUÑNON DE LARA, M.: El movimiento obrero en la historia de España, Madrid, Taurus, 1972, p. 11. DAVID, M.: Les travailleurs et le sens de leur histoire, París, Cujas, 1967, p. 94. En los mismos orígenes del movimiento sindical se detecta la posición del sindicato de llevar a cabo huelgas de solidaridad en apoyo de otros sectores enfrentados con sus empleadores. Vid., significativamente, WEBB, S. y WEBB, B.: Historia del sindicalismo, 1966-1920, trad. A. Gimeno, Madrid, Ministerio de Empleo y Seguridad Social, 1990, pp. 616 y 617.

${ }^{46}$ Vid. GARCÍA RUBIO, Ma. A.: "Las modalidades de huelga ilegal", en PÉREZ DE LOS COBOS Y ORIHUEL, F. (Dirs.) y MONREAL BRINGSVAERD, E. J. (Coord.), et al: Real Decreto-Ley 17/1977, de 4 de marzo, sobre relaciones de trabajo (Régimen legal y jurisprudencial de la huelga, el cierre patronal y el conflicto colectivo), Madrid, La Ley, 2014, pp. 625 y ss.

${ }^{47}$ STC 11/1981, de 8 de abril, fj. 9 [RTC 1981\11].

${ }^{48}$ En la práctica las huelgas de solidaridad no tienen por qué estar vinculadas al ámbito de la negociación colectiva. En un modelo sociopolítico de huelga como el que existe en nuestro país (se infiere más claramente de la regulación proyectada), la huelga no se estructura funcionalmente como un elemento de la negociación colectiva. Para la experiencia distinta de Alemania, véase ALONSO GARCÍA, M.: La huelga y el cierre empresarial, Madrid, Instituto de Estudios Económicos, 1979, p. 204. 
cualquier huelga de solidaridad. Conclusión tanto más claramente pertinente cuando se advierte la amplitud de los intereses cuya tutela puede ser objetivo de la huelga: según el Tribunal Constitucional, "hay que precisar que el adjetivo profesional que el texto que analizamos utiliza ha de entenderse referido a los intereses que afectan a los trabajadores en cuanto tales, no, naturalmente, en cuanto miembros de una categoría laboral específica" ${ }^{\text {"9 }}$.

En suma, se considera legal la huelga de solidaridad (cuando la solidaridad esté motivada ${ }^{50}$ ) en la que el interés defendido no es directamente deducible de vínculo profesional del trabajador huelguista, sino de la existencia de unos intereses de clase de los que se participa por el hecho de pertenecer a ella, o a un sector de ella, existiendo una conexión de intereses entre los trabajadores huelguistas ${ }^{51}$, aunque no reivindiquen nada para ellos mismos ${ }^{52}$.

\section{HUELGA ILEGAL Y HUELGA ABUSIVA: INTERESES OBJETO DE TUTELA Y ALGUNAS PROPUESTAS DE LEGE FERENDA}

En cuanto a las modalidades "finalistas" (intereses legítimamente perseguibles) de huelga, una nueva regulación legislativa acorde con el texto constitucional debería plantearse y partir del reconocimiento de la legitimidad de las huelgas que persigan la defensa de los intereses que le son propios a los trabajadores, incorporando las matizaciones hechas por el Tribunal Constitucional, de manera que ello conduciría a admitir las huelgas de solidaridad ${ }^{53}$, las huelgas con ocupación pacífica de lugares de trabajo $^{54}$ (éstas, evidentemente, remiten a una modalidad típica de ejercicio del derecho de huelga ${ }^{55}$, las huelgas sociopolíticas en defensa de intereses de los trabajadores (sólo

\footnotetext{
${ }^{49}$ STC 11/1981, de 8 de abril, fj. 21 [RTC 1981\11].

50 FLORENCIO THOMÉ, C.: "Huelga de solidaridad", en BAYLOS GRAU, A. P., FLORENCIO THOMÉ, C. y GARCÍA SCHWARZ, R. (Coords.) et al: Diccionario internacional de derecho del trabajo y de la seguridad social, Valencia, Tirant lo Blanch, 2014, p. 1051.

${ }^{51}$ MONEREO PÉREZ, J. L.: "La huelga como derecho constitucional: la técnica específica de organización jurídico-constitucional de la huelga (I)", en Temas laborales: Revista andaluza de trabajo y bienestar social, núm. 27, 1993, p. 83.

52 MARTÍN SERRANO, A, L.: "La huelga de solidaridad", en AA. VV.: Jurisprudencia Constitucional y Relaciones Laborales, Madrid, Centro de Estudios Constitucionales, 1983, pp. 221-255. MONEREO PÉREZ, J.L.: "Las modalidades de huelga: la normalización jurídica de las llamadas huelgas anómalas (I y II)", en revista Documentación Laboral, núms. 41 y 42, 1993-1994. AA. VV.: "Los fines de la Huelga", en MONEREO PÉREZ, J. L. (Coord.) et al: Derecho de huelga y conflictos colectivos. Estudio crítico de la doctrina jurídica, Granada, Comares, 2002, p. 122. SEMPERE NAVARRO, A. V.: "Huelgas ilegales y huelgas abusivas", en SANGUINETI RAYMOND, W. y CABERO MORÁN, E. (Coords.) et al: Sindicalismo y Democracia. El Derecho Sindical Español del profesor Manuel Carlos Palomeque treinta años después (1986-2016), Granada, Comares, 2017, p. 609.

${ }^{53}$ STC 11/1981, de 8 de abril [RTC 1981\11].

${ }^{54}$ Vid. ARESE, C.: "Huelga con ocupación del lugar de trabajo", en BAYLOS GRAU, A. P., FLORENCIO THOMÉ, C. y GARCÍA SCHWARZ, R. (Coords.) et al: Diccionario internacional de derecho del trabajo y de la seguridad social, Valencia, Tirant lo Blanch, 2014, pp. 1041 y ss.

${ }^{55}$ STC 22/1981, de 2 de julio [RTC 1981\22]. 
quedarían al margen de la legalidad las "huelgas insurreccionales" o "revolucionarias") 56 $\mathrm{y}$, asimismo, ciertos tipos de huelgas novatorias o durante la vigencia del convenio colectivo (que tengan por objeto materias no reguladas por el convenio durante su vigencia; las interpretativas de los preceptos o cláusulas del convenio colectivo; las motivadas por una alteración sobrevenida de circunstancias, etcétera) ${ }^{57}$. En este sentido, debería plantearse la desaparición de la regulación contenida en el art. 11 RDLRT, pues su mantenimiento arroja más sombras de dudas que de luz. Es un precepto que, a pesar de su reinterpretación por el Tribunal Constitucional, continúa manteniendo una fuerte impregnación de la lógica iusprivatista originaria.

En términos generales, la determinación legal (RDLRT) de las modalidades lícitas de huelga (realizadas de forma implícita), incluso con la aportación de la doctrina constitucional en relación a la misma, produce un efecto excesivamente restrictivo respecto del marco permitido por la Constitución. Entre los diferentes límites que producen dicho efecto conjunto son de realzar principalmente dos: la identificación del fenómeno de la huelga, en términos casi absolutos, con la cesación del trabajo; y la presunción del carácter abusivo de ciertas modalidades de huelga, en lugar de presumir su licitud. Sería deseable que una regulación legal orgánica, en desarrollo directo del art. 28.2 CE, ampliara de forma significativa el contenido del derecho de huelga, sin ceñirse de forma estrecha al contenido esencial delimitado por la doctrina del Tribunal Constitucional. En el sentido de que la noción legal de huelga ampararía la cesación total o parcial del trabajo o la alteración del normal desarrollo del mismo, realizada por los trabajadores, de forma colectiva y concertada, para la defensa de sus intereses. La experiencia acumulada, junto con la doctrina jurisprudencial al respecto, permitirían una opción legal ampliadora, con su correspondiente traducción en la ampliación de la tipología huelguística considerada lícita y la sustitución de la presunción de ilicitud o abuso por su presunción contraria de legalidad, como corresponde a la regulación de un derecho fundamental. Todo ello vendría a su vez compensado por una regulación más pormenorizada de los requisitos del ejercicio y desarrollo de la huelga, a fin de proteger los intereses y derechos de los trabajadores no huelguistas, de los empresarios (sean o no destinatarios directos de las mismas) y de los ciudadanos en general, especialmente en el momento de garantizar el mantenimiento de los servicios esenciales de la comunidad.

La regulación apriorística llevada a cabo por el art. 7.2 RDLRT (huelgas rotatorias, huelgas tapón o estratégicas, huelgas de celo o reglamento), por su parte, no encaja plenamente en la ratio inspiradora del art. 28.2 CE, el cual contiene una formulación amplia de la garantía del derecho de huelga y de las modalidades de ejercicio comprendidas en su contenido esencial. Desde esta perspectiva, es necesario decir que el Tribunal Constitucional amplía los contornos del derecho de huelga dando entrada a una serie de medidas de presión que en ningún caso podrían haberse considerado lícitas a la

\footnotetext{
${ }^{56}$ STC 36/1993, de 8 de febrero [RTC 1993136].

${ }^{57}$ STC 38/1990, de 1 de marzo [RTC 1990\38], STC 332/1994, de 19 de diciembre [RTC 1994\332] y STC 333/1994, de 19 de diciembre [RTC 1994।333]. 
luz de la redacción y de la filosofía restrictiva del RDLRT de 1977. En este orden de ideas, hay que objetar al Alto tribunal el que, tras esta interpretación inicialmente amplia, se haya corregido inmediatamente después al estimar que la admisión de principio de cualquiera de las modalidades de huelga es de estricta configuración legal. Con lo cual, actualmente, el RDLRT (en su interpretación por el Tribunal Constitucional) no está en la consonancia con la amplitud de los términos de la fórmula constitucional ex art. 28.2 CE.

Tampoco se ve la lógica de sus argumentaciones en torno al establecimiento de una presunción iuris tantum del abuso del derecho de huelga sólo en algunos casos. Aceptado por el propio Tribunal que el art. 7.2 RDLRT no contiene una relación cerrada de supuestos típicos de abuso del derecho de huelga, sino que éste se extiende a otros supuestos que contemplan aspectos diversos de la regulación de la misma, no tiene sentido que unas gocen de presunción de abusividad y otras de presunción de legalidad, como ocurre con las huelgas intermitentes, respecto de las cuales al no estar en la lista del art. 7.2 RDLRT, deberá presumirse su validez.

La expresión textual del legislador deja claro que del art. 7.2 se obtiene una presunción iuris tantum de abuso del derecho de huelga, lo que significa que quien pretenda extraer las consecuencias de la ilicitud o del carácter abusivo podrá ampararse en la presunción; pero también significa que la presunción admite prueba en contrario; por consiguiente, los huelguistas que utilizaren tal modalidad o tipo podrán probar que la utilización no fue abusiva $^{58}$.

Por otra parte, hay que aludir a uno de los puntos con mayor transcendencia de la doctrina del Tribunal Constitucional plasmada en la STC 11/1981, de 8 de abril ${ }^{59}$. Se trata de la aplicación de la teoría del abuso como límite a la huelga. A este respecto, y si bien es cierto que se han manejado conceptos iusprivatistas tales como el daño, la intención de dañar y la gravedad del perjuicio causado, con el consiguiente riesgo de desnaturalizar la eficacia del derecho de huelga, podemos decir que, globalmente considerada, la interpretación del tribunal se muestra coherente toda vez que la aplicación de la teoría del abuso sobre la huelga deja incólume la visión instrumental que de ella se predica en toda la sentencia. Pero es discutible su utilización indiferenciada para un derecho como el de la huelga que parte necesariamente de la finalidad de dañar, de causar un perjuicio. Pero ese perjuicio no puede trascender de lo razonablemente requerido por la propia actividad conflictiva y por las exigencias inherentes a la presión que la huelga necesariamente implica; el abuso de derecho sería sobrepasar ese límite ocasionando un perjuicio grave

\footnotetext{
${ }^{58}$ MONEREO PÉREZ, J.L.: "Las modalidades de huelga: la normalización jurídica de las llamadas huelgas anómalas (I y II)”, en revista Documentación Laboral, núms. 41 y 42, 1993-1994; LÓPEZ GANDÍA, J.: "Huelgas ilegales y abusivas", en Revista del Instituto de Estudios Económicos (Ejemplar dedicado a "La regulación del Derecho de Huelga en España"), núm. 2 y 3, 2010.

${ }_{59}$ Concretando la posición del Tribunal Constitucional sobre las huelgas políticas: STC. 36/1993, de 8 febrero [RTC 1993\36], STC. 183/2006, de 19 junio [RTC 2006\183], STC. 191/2006, de 19 junio [RTC 2006\19] y STC. 193/2006, de 19 junio [RTC 2006\193]. 
e intencionado, esto es, una grave desorganización de la actividad productiva y un daño desproporcionado ${ }^{60}$. Por otra parte, el Tribunal Constitucional invierte el juego ordinario de la teoría del abuso de derecho. El carácter abusivo de una forma de huelga concreta será una excepción a modalidades huelguistas que, en principio, gozan de presunción de legitimidad, recayendo lógicamente la prueba sobre el que lo pretende (incumbe a quien lo alega). No se puede considerar abusiva a priori ninguna modalidad de huelga; una futura regulación tendría que limitarse a establecer unos criterios-guía que permitan valorar si el ejercicio de una determinada huelga incurre efectivamente en abuso de derecho, que en todo caso será excepcional. Corresponderá al juez apreciar la concurrencia en el caso contemplado de los elementos que tipifican la existencia de extralimitación en el ejercicio del derecho, y deberá hacerlo con extraordinaria cautela atendiendo sobre todo a la especialidad del derecho subjetivo de huelga. La nueva regulación futura debería salvar las cuestiones planteadas, de un lado, invirtiendo la presunción iuris tantum a favor de los trabajadores e imprimiendo una nueva reformulación de la materia, tanto desde el punto de vista político-jurídico como técnico. Y, de otro, estableciendo unos parámetros objetivos por los que determinar la abusividad de una huelga partiendo de un criterio que sería mucho más coherente: no hay modalidades de huelga abusivas per se, sino concretas formas de ejercicio abusivo de las mismas de acuerdo con los parámetros objetivos mencionados. Sería deseable que la próxima propuesta legal caminase en esta línea, contribuyendo de ese modo a la normalización jurídica de estas huelgas anómalas toda vez que las situaría al mismo nivel de las tradicionales formas de huelga y ello, a su vez, comulgaría más con la amplitud de los términos de la fórmula constitucional que se consagra en el art. 28.2 CE. Sería aconsejable también evitar la confusión a la que nos ha llevado la actual normativa al hacerse referencia a tres categorías de lo antijurídico: ilegalidad, abusividad e ilicitud cuando, desde la teoría general del abuso del derecho, no existe diferencia entre las dos últimas $^{61}$; y establecer, en fin, una serie de criterios objetivos para la determinación del abuso caso por caso, de entre los que debería excluirse la intencionalidad del daño, priorizando la relación de causalidad entre la modalidad de la huelga y los daños inferidos. Con ello, sería posible la normalización jurídica de las actualmente consideradas huelgas anómalas o presuntamente abusivas, por cuanto que desde ese momento se habrían colocado ex lege en situación de proximidad con las formas tradicionales de actuación huelguística ${ }^{62}$.

\footnotetext{
${ }^{60}$ STC 72/1982, de 2 de diciembre [RTC 1982\72] y STC 41/1984, de 21 de marzo [RTC 1984\41].

${ }^{61}$ MARTÍN BERNAL, J. M.: El abuso del derecho, Madrid, Montecorvo, 1982, pp. 136-140.

${ }^{62}$ MONEREO PÉREZ, J. L.: "La titularidad del derecho de huelga y sus manifestaciones anómalas, ilegales o abusivas. Propuestas de reforma", en Revista del Instituto de Estudios Económicos (Ejemplar dedicado a "La regulación del Derecho de Huelga en España"), núm. 2 y 3, 2010, pp. 227 y ss. 


\section{HUELGAS POLÍTICAS Y REFERENCIAS AL OLVIDADO PROYECTO DE LEY ORGÁNICA}

La motivación de la huelga viene establecida en el art. 28.2 CE, al precisar que la huelga es un derecho que sirve para la defensa de "sus intereses". Por su parte, el art. 11.a) RDLRT considera ilegal la huelga "cuando se inicie o sostenga por motivos políticos o con cualquier otra finalidad ajena al interés profesional de los trabajadores afectados". El art. 8.a) Proyecto de Ley Orgánica de Huelga de 1992, previamente negociado con las organizaciones sindicales más representativas (en adelante, $\mathrm{PLOH}$ ), proponía que fueran consideradas ilegales "las huelgas que tengan por objeto subvertir el orden constitucional $y$, en particular, obstaculizar el libre desarrollo de la actividad parlamentaria". E1 tratamiento era más matizado en el PLOHN, art.5.1.a), que restringía claramente el alcance posible de la prohibición al considerar como ilegales exclusivamente a "las huelgas que tengan por objeto subvertir el orden constitucional".

En este tipo de huelgas la problemática de los fines se conecta también con la del "sujeto pasivo" de la huelga, estableciéndose una cierta disociación entre "sujeto pasivo" y "destinatario" de la medida de presión, porque ex definitione en las huelgas políticas el sujeto pasivo sigue siendo el empresario, a pesar de que éste no dispone de los medios y del poder para satisfacer las pretensiones de los huelguistas ${ }^{63}$. Esto ha llevado a afirmar que el modelo de huelga escogido por el texto constitucional no incluye la huelga política, y de ahí la legalidad de la exclusión de su campo de acción operada por el art. 11.a) RDLRT $^{64}$.

No obstante, debe tenerse en cuenta que "la huelga puede tener por objeto reivindicar mejoras en las condiciones económicas, o, en general, en las condiciones de trabajo, y puede suponer también una protesta con repercusión en otras esferas o ámbitos" ${ }^{65}$. Por tanto, se admite el uso de la huelga para la protección de los intereses económicos y sociales de los trabajadores ${ }^{66}$.

\footnotetext{
${ }^{63}$ MONEREO PÉREZ, J. L. y ORTEGA LOZANO, P. G.: El derecho de huelga: configuración y régimen jurídico, Cizur Menor (Navarra), Thomson/Aranzadi, 2019, p. 261.

${ }^{64}$ Cfr. GARCIA BLASCO, J.: El derecho de huelga en España: calificación y efectos jurídicos, Barcelona, Bosch, 1983, p. 73. También BAYLOS GRAU, A.: "Replanteamientos y novedades en la regulación jurídica de la huelga”, en Revista de Derecho Social, núm. 82, 2018, pp. 179 y ss. La evolución jurisprudencial reciente sobre la admisibilidad de las huelgas sociopolíticas permite apreciar cómo en alguna sentencia se argumentó en base al criterio de que el empleador no podría satisfacer las pretensiones motivadoras de la acción huelguística. Véase el excelente comentario sobre la evolución de la doctrina jurisprudencial al respecto hecho por BORRAJO DACRUZ, E.: "Poder normativo y poder judicial en la elaboración del nuevo Derecho del Trabajo", en $A L$, núm. 43, 1992, pp. 767-775. En esta evolución la jurisprudencia parece ya decantarse (aún vigente, recuérdese, el art. 11.a) RDLRT) por la legitimidad de tales tipos de huelgas. También SEMPERE NAVARRO, A. V.: "Huelgas ilegales y huelgas abusivas", en SANGUINETI RAYMOND, W. y CABERO MORÁN, E. (Coords.) et al: Sindicalismo y Democracia. El Derecho Sindical Español del profesor Manuel Carlos Palomeque treinta años después (1986-2016), Granada, Comares, 2017, p. 608.

${ }^{65}$ STC 259/2007, de 19 de diciembre [RTC 2007/259].

${ }^{66}$ PÉREZ DE LOS COBOS Y ORIHUEL, F.: "Sobre las limitaciones de la regulación jurisprudencial del derecho de huelga", en Revista del Ministerio de Empleo y Seguridad Social, núm. 108, 2014, p. 304. 
El tema, sin embargo, se resuelve perfectamente cuando se repara en el carácter de derecho fundamental de la huelga (versión "reformulada" en el constitucionalismo social de los clásicos derechos subjetivos públicos de libertad). En el sistema constitucional se consagra un sistema abierto de derecho de huelga que no admite, en todo caso, su restricción al modelo-tipo puramente contractual. La huelga no se concibe exclusivamente como un instrumento auxiliar de la negociación colectiva, adquiere una funcionalidad más amplia en otros campos de la vida social.

Desde una perspectiva estrictamente constitucional no parece oponible a la Constitución una delimitación de los objetivos perseguibles con la huelga que atienda a todas las abstenciones colectivas del trabajo dirigidas a hacer valer los intereses de los trabajadores frente a cualquier instancia ${ }^{67}$. Se podría decir que, en la Constitución, la huelga se configura como un "derecho instrumental a la obtención de bienes económico-sociales que el sistema constitucional vincula a las exigencias de tutela y de desarrollo de la personalidad de los trabajadores dependientes" ${ }^{68}$. En la huelga política los trabajadores actúan no solo en el sentido estricto de trabajadores sino también en su condición de ciudadanos $^{69}$.

Desde este punto de vista, parece que asistía la razón a los recurrentes del art. 11.a) RDLRT (que establece la ilegalidad sin más de todo tipo de huelga política) ${ }^{70}$, quienes alegaban, con apoyo en el principio de igualación sustancial preordenado en el art. 9.2 $\mathrm{CE}$, que precisamente la huelga es un instrumento útil para contribuir al logro de ese objetivo del constituyente. Por otra parte, para los recurrentes, el derecho constitucional de huelga está configurado como derecho subjetivo público de eficacia erga omnes, en orden a la defensa de los más amplios intereses de los trabajadores en su condición de tales en todos los ámbitos de la vida social y no sólo exclusivamente en el plano

\footnotetext{
${ }^{67}$ La norma fundamental ex art. 28.2 daría acogida a las huelgas sociopolíticas, o incluso una breve cesación en el trabajo por motivos políticos (huelga "de advertencia").

${ }^{68}$ Estos son los mismos términos utilizados por la sentencia $n^{\circ} .123$ de la Corte Constitucional italiana en cita de MENGONI, L.: “Corte constitucional italiana y Derecho sindical”, en TL, núm.19-20, 1990, pp. 36 y 37. El autor subraya que "la noción de huelga política ha quedado restringida a las huelgas dirigidas a presionar al Parlamento o al Gobierno con fines ausentes de toda relación con las condiciones de trabajo". De este modo en el art. 8.a) PLOH, se admitía la huelga política, entendida como aquella que incide en el campo de la actividad política del Parlamento o del Gobierno, con excepción de los dos casos límites consistentes en la que va dirigida a subvertir el ordenamiento constitucional o a impedir o a obstaculizar el libre ejercicio de los poderes legítimos a través de los que se expresa la soberanía popular (es decir, la actividad del Parlamento y/o del Gobierno). Se debe anotar la afinidad que guardaba la fórmula utilizada en el art. 8.a) PLOH [nótese que según este precepto son ilegales "las huelgas que tengan por objeto subvertir el orden constitucional y, en particular, obstaculizar el libre desarrollo de la actividad parlamentaria"] con esta doctrina sentada por el Alto Tribunal del país vecino (por otra parte, tan cercano al nuestro en este orden de problemas), hasta el punto de que parece haber sido tomada prestada. De cualquier modo, la formulación del art. 8.a) PLOH se presta a interpretaciones difícilmente ajustables al texto constitucional y en virtud de ella se pudiera llegar a prohibir incluso las huelgas de imposición económico-política. De ahí, que aquí se valorara tan positivamente la formulación que se terminó realizando en el art. 5.1a) PLOHN.

${ }^{69}$ AA. VV.: "Los fines de la huelga", en MONEREO PÉREZ. J. L. (Coord.) et al: Derecho de huelga y conflictos colectivos. Estudio crítico de la doctrina jurídica, Granada, Comares 2002, p.119.

${ }^{70}$ Según ese precepto la huelga es ilegal "cuando se inicie o sostenga por motivos políticos o con cualquier otra finalidad ajena al interés profesional de los trabajadores afectados". 
estrictamente profesional; es decir, en la doble condición de los trabajadores como partes de una relación laboral y como miembros de una clase social. Pero en verdad el tribunal no se pronuncia con claridad respecto al verdadero alcance de los intereses tutelables mediante la huelga.

Es lo cierto que existen datos suficientes en la STC 11/1981, de 8 de abril ${ }^{71}$, que avalan una concepción restrictiva de los fines de la huelga, y el más importante de convalidar la constitucionalidad de la ilegalidad de las huelgas políticas en los términos establecidos en el RDLRT. Se debe señalar que el art. 11.a) RDLRT no fue tachado de inconstitucionalidad, lo que supone tácitamente aceptar su adecuación a la Constitución. Pero, por otra parte, el Tribunal Constitucional muestra su deliberada ambigüedad cuando expresa que $\mathrm{e}^{72}$ : "el texto del art. 28 -derecho de los trabajadores para la defensa de sus intereses- pone en muy clara conexión la consagración constitucional y la idea de consecución de igualdad económica y social. La conclusión que de ello se extrae es que no nos encontramos ante el fenómeno de huelga protegido por el art. 28 de la Constitución cuando se producen perturbaciones en la producción de bienes y de servicios o en el normal funcionamiento de estos últimos que se introducen con el fin de presionar sobre la Administración Pública o sobre los órganos del Estado para conseguir que se adopten medidas gubernativas o que se introduzca una nueva normativa más favorable para los intereses de una categoría (por ejemplo, de empresarios, de concesionarios de servicios, etcétera)" ${ }^{\text {,73. }}$.

Sin embargo, este posicionamiento del Tribunal Constitucional ${ }^{74}$, no encuentra soporte en el sistema constitucional del derecho de huelga (en lo que se refiere a una posible lectura restrictiva sobre la legitimidad de la huelga sociopolítica de los trabajadores dependientes). Es suficiente reparar en la función asignada constitucionalmente al derecho de huelga. Lo más conforme al sistema constitucional es entender que tanto desde un punto de vista lexicológico como sistemático y de política jurídica, la expresión "para la defensa de sus intereses", ex art. 28.2 CE, tenía el sentido de indicar que los intereses tutelados por el derecho de huelga son los que como tales hagan suyos los trabajadores, los que éstos identifiquen ${ }^{75}$.

De modo que la indefinición constitucional del tipo de intereses objeto de la huelga debe ser interpretada como la admisibilidad de todos aquellos que se puedan detectar como

\footnotetext{
${ }^{71}$ STC 11/1981, de 8 de abril, fj. 9 [RTC 1981\11].

72 Aunque refiriéndose a los trabajadores autónomos o independientes, sin aclarar, cuando debía hacerlo porque estaba incorporado al petitum del recurso de inconstitucionalidad, cual era efectivamente su criterio respecto a las huelgas de "imposición económico-política" de los trabajadores por cuenta ajena.

${ }^{73}$ STC 11/1981, de 8 de abril, fj. 12 [RTC 1981\11].

${ }^{74}$ De entenderse prohibitivo indirectamente también de las huelgas sociopolíticas de los trabajadores por cuenta ajena.

${ }^{75}$ Véase el texto del Escrito de Alegaciones complementarias del recurrente, en MATIA PRIM, J., SALA FRANCO, T., VALDÉS DAL-RÉ, F. y VIDA SORIA, J.: Huelga, cierre patronal y conflictos colectivos, Madrid, Civitas, 1982, pp. 268-271. 
pertenecientes a los trabajadores en su condición de productores y de ciudadanos, es decir, en conexión con la ya advertida consideración de la ciudadanía social ${ }^{76}$.

Fundamento importante para la admisibilidad de las huelgas de imposición económicopolítica lo constituye la cláusula remisoria contenida en el art. 10.2 CE, toda vez que las huelgas sociopolíticas son admitidas por el Comité de Libertad Sindical de la OIT $^{77}$ y la Comisión de Expertos de la Carta Social Europea. Se entiende, pues, que la configuración constitucional del derecho de huelga se corresponde con un modelo abierto y dinámico. Según este modelo, la huelga es un medio de autotutela de los trabajadores por cuenta ajena en todos los ámbitos de la vida social en que se adoptan decisiones atinentes a sus intereses, y no sólo en el ámbito de las relaciones laborales. Para esta concepción la huelga puede ejercitarse frente a todas las instancias de poder cuyas decisiones puedan afectar a los intereses de los trabajadores, y no sólo frente al empresario ${ }^{78}$.

Aun cabe traer a colación otro elemento relevante para fijar el diseño constitucional de la huelga sociopolítica en el texto constitucional. Se trata de la consideración del papel atribuido a los sindicatos en el sistema político. En tal sentido, conviene tener en cuenta que los sindicatos son precisamente uno de los elementos esenciales del sistema político como se deduce del art. 7 CE (cfr. art. $131 \mathrm{CE}$ ). De modo que la referencia a los intereses económicos y sociales que le son propios no puede sino conectarse con la función general del sindicato, es decir, con las distintas vertientes o dimensiones de la actividad sindical. Adviértase, por otra parte, que en las sociedades de capitalismo maduro los partidos y sindicatos no se diferencian tanto por sus fines, como por los medios que unos y otros utilizan $^{79}$. Desde este punto de vista se puede identificar la índole de los intereses defendibles mediante la huelga entendiendo que abarca la defensa de los intereses

\footnotetext{
${ }^{76}$ La existencia de un espacio amplio para el ejercicio del derecho de huelga (es decir, del círculo de intereses que pueden ser defendidos a través de la huelga), se conecta con su configuración jurídico-política general en el sistema constitucional. Así, en países como España (también Francia e Italia singularmente) que conforman constitucionalmente el derecho de huelga como un derecho de la persona o derecho fundamental, el derecho de huelga mira a satisfacer la exigencia de tutela de la personalidad del trabajador (ahora en el seno de los grupos o clases sociales) en todos los ámbitos de la vida social. Desde este punto de vista, la "politicidad" potencial de la huelga adquiere plena coherencia en el sistema diseñado por el constituyente, con todos los límites de ejercicio que se quieran deducir del frondoso tejido constitucional.

77 Téngase en cuenta que es principio general de la OIT que "el derecho de huelga es uno de los medios esenciales a disposición de los trabajadores y sus organizaciones para promover y defender sus intereses económicos y sociales, es decir, no sólo los relativos al logro de mejores condiciones de trabajo y la satisfacción de las reivindicaciones colectivas de orden profesional, sino también los relacionados con la búsqueda de soluciones para los problemas de política económica y social o de índole laboral que atañen directamente a los trabajadores". Cfr. OIT.: "La libertad sindical", 2a ed. (revisada), Ginebra, 1988, p. 68. Se subraya en esta línea la diferencia entre huelgas que defienden intereses "que están vinculados a la búsqueda de soluciones para problemas generales de política económica y social" (huelgas socio-políticas) y "las huelgas de carácter puramente político".

${ }^{78}$ MONEREO PÉREZ, J. L.: "La huelga como derecho constitucional: la técnica específica de organización jurídico-constitucional de la huelga (II)", en Temas laborales: Revista andaluza de trabajo y bienestar social, núm. 28, 1993, p. 87.

${ }^{79}$ Vid. RAMÍREZ MARTÍNEZ, J. M.: "Huelga y cierre patronal en la Constitución española", en AA. VV.: Estudios de Derecho del Trabajo en memoria del profesor Gaspar Bayón Chacón, Madrid, Civitas, 1980, pp. 458 y 459. 
generales de los trabajadores, siendo ello plenamente coherente con la referencia en la fórmula constitucional de "sus" intereses.

Esto, sin duda, pone de relieve la estrecha vinculación que tiene la identificación del objeto de la huelga con el diseño normativo del modelo de huelga. Ello se comprende perfectamente porque la negación de la huelga política va unida casi siempre política y dogmáticamente a la limitación y regularización del derecho de huelga mediante su unión funcional al sistema de negociación colectiva, es decir, al llamado "modelo contractual" de huelga ${ }^{80}$. La concepción de la huelga como mero instrumento de la eficacia del sistema de negociación colectiva se corresponde con la metodología funcionalista proyectada en el instituto jurídico de la huelga, y, en general, respecto a la ordenación de los conflictos colectivos de trabajo ${ }^{81}$.

El error de partida de esta metodología unilateralista reside en desconocer que el examen de las funciones no debe sustituir al de las causas, porque una vez que previamente han sido establecidas éstas, es menester comprobar de qué modo han contribuido a la formación de las relaciones funcionales de conflicto. El dualismo metodológico se impone inevitablemente.

Así pues, si se tiene en cuenta ese conjunto de criterios hermenéuticos será muy difícil llegar a una conclusión muy distinta de la doctrina del Comité de Libertad Sindical de la OIT que distingue entre huelgas políticas "puras" y huelgas socio-políticas ${ }^{82}$. Esto deja

\footnotetext{
${ }^{80}$ Véase la exposición de este modelo en BLANKE, T.: "Derecho de huelga de los servicios públicos en Alemania", en Gaceta Sindical, núm. 98, 1991, pp. 24 y 25.

${ }^{81}$ MONEREO PÉREZ, J. L.: "La constitucionalidad de las huelgas sociopolíticas (A propósito de la STC 36/1993, de 8 de febrero)", en AA. VV.: Homenaje al profesor Juan García Abellán, Murcia, Universidad de Murcia, 1994, p. 230.

${ }^{82}$ Incluso cuando se trate de una huelga política en sentido estricto o "pura" (es decir, desvinculada de los intereses colectivos de los trabajadores, tendiendo a hacer prevalecer una determinada orientación política) se ha advertido oportunamente (GIUGNI, G.: Derecho sindical, trad. y est. preliminar de J. Vida Soria y J. Montalvo Correa, Madrid, Ministerio de Trabajo y Seguridad Social, 1983, p. 246) que, pese a todo el recurso a la huelga, aunque esté fuera de los confines que el derecho ha establecido, no supone necesariamente, a diferencia con el pasado, que aparezca siempre una figura delictiva. Si no entra en el tipo penal (dirigida a subvertir la seguridad del Estado) se estaría ante la llamada huelga-libertad, ilícita desde la perspectiva contractual y tan sólo ilegal desde la vertiente penal, cuando exista un dolo específico en esa voluntad de subvertir la seguridad del Estado. Vid. VIDA SORIA, J.: "Régimen jurídico de la huelga en Italia", en AA.VV.: La huelga en Europa, en Cuadernos de Estudios Laborales, núm. 1, 1975, p. 124. VIDA SORIA, J.: "Comentario al art. 28.2 de la Constitución Española", en ALZAGA VILLAAMIL, O. (Dir.) et al: Comentarios a las Leyes Políticas. Constitución Española de 1978, tomo III, Madrid, Edersa, 1983, p. 237. SALA FRANCO, T. y ALBIOL MONTESINOS, I.: Derecho Sindical, Valencia, Tirant lo Blanch, 1991, p. 449. DE LA VILLA GIL, L. E., GARCIA BECEDAS, G. y GARCIA PERROTE ESCARTIN, I.: Instituciones de Derecho del Trabajo, Madrid, Ceura, 1991, pp. 460 y 461. MARTIN VALVERDE, A.: "Huelga laboral y huelga política: un estudio de modelos normativos", en RIVERO LAMAS (coord.) et al: El derecho del trabajo ante el cambio social y político, Zaragoza, Universidad de Zaragoza, 1977, p. 85. GARCIA BLASCO, J.: El derecho de huelga en España: calificación y efectos jurídicos, Barcelona, Bosch, 1983, p. 82. Véase también CARINCI, F. et al.: Diritto del Lavoro. Vol. 1: Il Diritto Sindacale, Torino, UTET, 1983, pp. 344-346. Y ello aun no estando la huelga estrictamente política (por medio de las cuales se ejercen acciones en defensa de intereses generales de todos los ciudadanos) dentro del art. 28.2 CE.

De este modo, delimitado el espacio cubierto por el derecho de huelga, resta admisible también un espacio cubierto por la libertad de huelga política pura no atentatoria contra el sistema democrático (como tal lícita ISSN: 2174-6419 Lex Social, vol. 11, núm. 2 (2021)
} 
en la práctica fuera de la garantía constitucional a aquellas huelgas que tengan por objeto subvertir el orden constitucional, que son las únicas que pueden considerarse en verdad un atentado contra el sistema democrático, precisamente por ello serán huelgas lícitas aquellas que actúen la pretensión de su defensa ${ }^{83}$.

El Tribunal Constitucional implícitamente ha establecido esa vinculación sociopolítica de la huelga sindical: "no puede en absoluto decirse que el Real Decreto-Ley 17/77 esté impidiendo las llamadas huelgas sindicales. Esa conclusión no es posible desde el momento en que el art. 7 de la Constitución reconoce a los sindicatos de trabajadores el carácter de organismos básicos del sistema político" ${ }^{" 4}$.

Conviene tener en cuenta que el art. 8.a) PLOH, no declaraba explícitamente como ilegales todas o cualquier forma de huelga política, incluidas las "puras", sino dos variantes tipológicas de la misma, a saber: "las huelgas que tengan por objeto subvertir el orden constitucional y, en particular, obstaculizar el libre desarrollo de la actividad parlamentaria". El problema se hubiera planteado con seguridad con la interpretación de lo que se debería de entender por "obstaculizar el libre desarrollo de la actividad parlamentaria", pues se trata de un concepto jurídicamente indeterminado que exige concreción y reclama, por ello mismo, una actividad creativa de los tribunales. Se estaría nuevamente ante un concepto jurídico indeterminado, que estaría llamado a servir de límite al ejercicio del derecho de huelga. Ello supondría asumir la praxis de que su contenido en principio indeterminado ha de ser concretado por los tribunales, abriéndose así un amplio espacio para la actividad creativa de los jueces. Se estaría ante uno de los supuestos típicos del llamado "derecho de los juristas", en el sentido de que éstos contribuyen de una manera especial, mediante actividad "creadora", al desarrollo del

penalmente pero no civilmente, garantizada respecto al Estado, pero no con inmunidad civil frente al empleador). Pero admitir esto es mucho, o más de lo que una primera perspectiva podría sospecharse: porque mientras la huelga de imposición económico-política continúa obviamente siendo considerada un derecho, la huelga con fines políticos (huelga política "pura") deja de ser considerada un delito (excepción de los supuestos de huelga contrarias al orden democrático constitucional, a las que se ha hecho referencia antes), para ser elevada a libertad.

El Comité de Libertad Sindical de la OIT ha admitido las huelgas sociopolíticas, pero no las huelgas políticas puras (cfr. 139 Informe de 1974, casos 737 y 744), por lo que el art. 11.a) RDLRT rectamente interpretado sólo puede referirse a la prohibición de éstas últimas. De cualquier modo, el art. 5.1.a) PLOHN se situaba en la línea de una preexistente dirección jurisprudencial favorable a la admisibilidad de las huelgas sociopolíticas, restringiendo el alcance que pudiera concedérsele al art. 11.a) RDLRT.

${ }^{83}$ Es más, aún en el caso de que se considerase que la huelga política no forma parte del contenido esencial (lo cual es discutible porque aquí no se trata de excluir las formas de ejercicio del derecho, sino excluir fines inherentes a la huelga en el sistema de la Constitución) del derecho de huelga, ello no impedirá que "una Ley posterior igualmente constitucional las declare legales. La huelga política resulta ser, así, ilegal pero no inconstitucional". Cfr. MATIA PRIM, J., SALA FRANCO, T., VALDÉS DAL-RÉ, F. y VIDA SORIA, J.: Huelga, cierre patronal y conflictos colectivos, Madrid, Civitas, 1982, p. 81. También UGARTE CATALDO, J. L.: "Huelga política", en BAYLOS GRAU, A. P., FLORENCIO THOMÉ, C. y GARCÍA SCHWARZ, R. (Coords.) et al: Diccionario internacional de derecho del trabajo y de la seguridad social, Valencia, Tirant lo Blanch, 2014, pp. 1063 y ss.

${ }^{84}$ STC 11/1981, de 8 de abril, fj. 11 [RTC 1981\11]. 
contenido del derecho; es decir, que no sólo piensan hasta sus últimas consecuencias las ideas del legislador ${ }^{85}$.

Pero el precepto en cuestión no podría suponer la exclusión de formas de huelga "política" que se limiten a servir de cauce de manifestación de la libertad de expresión de opiniones e ideas, a riesgo de no superar la tacha de inconstitucionalidad. Es oportuno reparar en el principio pluralista y en la base constitucional de apoyo a una participación efectiva de los ciudadanos en la actividad política. Se debe recordar, por otra parte, que la huelga es también un cauce de participación en todos los ámbitos de la vida social ${ }^{86}$.

Sin embargo, es más que probable que, en caso de que decidiera regularse el derecho de huelga por ley orgánica, la fórmula utilizada fuera parecida a la que se preveía en el art. 5.1.a) del PLOHN, que limitaba al ámbito material de la prohibición a las huelgas que "tengan por objeto subvertir el orden constitucional"87. Esta opción de política legislativa es más acorde con la dimensión constitucional del derecho de huelga y menos problemática para su aplicación práctica. El giro operado con la última formulación es

${ }^{85}$ En virtud de tales conceptos jurídicos quien aplica la ley adquiere mayor independencia frente a ella, precisamente porque el concepto indeterminado es un concepto cuyo contenido y alcance es en gran medida incierto. Y es cometido del jurista práctico el hallazgo de ese contenido en principio incierto. Vid. ENGISCH, K.: Introducción al pensamiento jurídico, trad. E. Garzón Valdés, Madrid, Ediciones Guadarrama, 1967, p. 139. También, ENGISCH, K.: Introducción al pensamiento jurídico, edición al cuidado de J. L. Monereo Pérez, Granada, Comares (Colección Crítica del Derecho), 2001, passim.

${ }^{86}$ Reténgase el dato político de que durante la misma gestación del PLOH, el Gobierno ya había insinuado la ilegitimidad de promover la huelga frente a un Proyecto de Ley de Huelga que inició su tramitación parlamentaria. No es este el sentido de que hubiera debido otorgarse al art. $8 \mathrm{PLOH}$, porque la huelga adquiere la dimensión de un cauce de expresión de opiniones o manifestación del pensamiento, permaneciendo enteramente "libres" las instituciones parlamentarias para desarrollar su actividad. El PLOH utilizaba así una fórmula prestada de la famosa sentencia de la Corte Constitucional Italiana de 27 de diciembre de 1974 que admitía la huelga política como una forma de presión legítima dirigida contra los poderes públicos y un medio apto para remover los obstáculos que impidan la igualdad real entre los ciudadanos. Pero, nótese, se consideraban ilegales por la Corte italiana las huelgas políticas encaminadas a subvertir el ordenamiento constitucional democrático u obstaculizar el libre ejercicio de los poderes legítimos en los cuales se expresa la soberanía popular. Lo que evidentemente no impidió a la Corte admitir las huelgas dirigidas a la salvaguardia de la democracia y de presión económico-política para la tutela de interés colectivo de las clases trabajadoras.

${ }^{87}$ Aquí el concepto jurídico indeterminado aparece en el "supuesto de hecho legal" (es decir, formando parte del conjunto de presupuestos que condiciona la ordenación jurídica de la consecuencia jurídica) de la proposición jurídica -y no en su consecuencia jurídica- (la consecuencia jurídica, es obvio, se integra con la ilegalidad de la huelga para el caso de que se actualice puntualmente el supuesto de hecho normativo). Por esta vía sin duda se configura legalmente un supuesto de hecho unitario delimitador del ámbito de la acción ilícita. Se podría decir respecto al supuesto de hecho legal del art. 5.1.a) PLOHN, que contiene un supuesto de hecho sustancialmente unitario de la acción no permitida. En el bien entendido que la cláusula general es una redacción expresiva de los supuestos de hecho que abarca con gran generalidad un campo de casos y les señala su correspondiente tratamiento jurídico. El problema de los conceptos jurídicos indeterminados adquiere una particular trascendencia respecto a la noción constitucional de "servicios esenciales" para la comunidad, en el sentido de servir de límite constitucional directo del ejercicio del derecho de huelga. Se podría proyectar para este último supuesto las consideraciones realizadas aquí. Vid. ENGISCH, K.: Introducción al pensamiento jurídico, trad. E. Garzón Valdés, Madrid, Ediciones Guadarrama, 1967, pp. 137 y ss. También, ENGISCH, K.: Introducción al pensamiento jurídico, edición al cuidado de J. L. Monereo Pérez, Granada, Comares (Colección Crítica del Derecho), 2001, passim. Sobre los conceptos jurídicos indeterminados y el derecho de huelga se volverá más adelante en el marco del tratamiento de las huelgas en servicios esenciales. 
importante, porque reclamando la interpretación a contrario, todas las restantes huelgas políticas gozan, en principio, de la presunción de legalidad. Se hace referencia, es claro, a las llamadas huelgas de imposición económico-política, cuya legitimidad se deducía en el fondo del mismo texto constitucional, pero siempre -y he aquí el alcance del límite legal posible de las mismas- que no sean "insurreccionales", es decir, que tengan por objeto "subvertir el orden constitucional". Se trataría de las "huelgas revolucionarias" (así calificadas con independencia de la orientación política de fondo que las inspire), en cuyo caso el derecho cede su papel a los medios de acción política directa y dará cuenta ulteriormente de su resultado práctico ${ }^{88}$.

A partir del art. 5.1.a) PLOHN, no hubiera cabido ya hacer planteamientos maximalistas (huelga sí-huelga no) sobre la admisibilidad de las huelgas políticas, sino sobre el tipo de huelga política legalmente admisible, pues el sistema legal hubiera considerado lícitas las huelgas con finalidad política, con la única excepción de los supuestos excluidos expresamente en dicho precepto. De manera que los otros tipos de huelgas políticas hubieran gozado de la presunción de licitud, tan sólo destruible mediante prueba en contrario de una motivación de fondo realmente detenida al subvertir el orden constitucional.

En suma, el derecho huelga "política" parece difícil que pueda resolverse negativamente teniendo en cuenta la función del sindicato como "actor político" (art. 7 y 131 CE) en el sistema constitucional ${ }^{89}$. Se tendrá que aceptar -como dijera GALLART FOLCH ${ }^{90}$ - que ciertos conflictos sociales adquieren proyecciones extralaborales que no pueden ser ignoradas por quienes intenten dar una explicación integral y un tratamiento jurídico adecuado a ese importantísimo fenómeno contemporáneo que es el sindicalismo y sus medios de acción. Por otra parte, la inherencia de la actividad política al fenómeno sindical es un hecho histórico innegable ${ }^{91}$.

${ }^{88}$ Reflexiones sobre la revolución como hecho y el ordenamiento jurídico, en ROMANO, S.: "Voz, Revolución y Derecho", en ROMANO, S.: Fragmentos de un Diccionario Jurídico, trad. S. Sentís Melendo y M. Ayerra Redín, Buenos Aires, Ediciones Jurídicas Europa-América, 1964, pp. 375 y ss. ROMANO, S.: Fragmentos de un Diccionario Jurídico, edición al cuidado de J. L. Monereo Pérez, Granada, Comares (Colección Crítica del Derecho), 2002.

${ }^{89}$ Esto es admitido, desde una perspectiva nada sospechosa de excesos ideológicos, por ZANGARI, G.: "Diritto di sciopero e sindacto come "actore" político", en ZANGARI, G.: Il Dirito di sciopero, Milano, Giuffré, 1976, pp. 447 y ss.

${ }^{90}$ Cfr. GALLART FOLCH, A.: "Proyecciones extra-laborales en los conflictos colectivos de trabajo", en AA.VV .: Contratti collettivi e controversie collettive di lavoro. Studi in memoria di Lodovico Barassi, Padova, Cedam, 1965, pp. 213 y ss.

${ }^{91}$ En verdad, tras la negativa a ver una realidad tan evidente como esta se oculta una operación de política del Derecho bien definida: el científico social puede comprobar que la sustracción de la esfera de "lo político" del ámbito posible de la acción huelguística se inscribe en el intento de limitar las señas del fenómeno sindical. Cfr. TREU, T.: "L'attività politica del sindicato", en Politica del Diritto, núm. 2, 1975, pp. 177 y ss. En este sentido, DURÁN LÓPEZ, F.: "Derecho de huelga, sociedad civil y sociedad política", en RIVERO LAMAS (coord.) et al: El derecho del trabajo ante el cambio social y político, Zaragoza, Universidad de Zaragoza, 1977, p. 135. Una reflexión comparada sobre la huelga política en RAMÍREZ MARTÍNEZ, J. M.: "La huelga política", en AA. VV.: La huelga en España, cuaderno núm. 2 del Instituto de Estudios Laborales, Madrid, 1975 , pp. 41 y ss. En realidad, los límites entre "lo político" y "lo económico" se van haciendo cada vez más ISSN: 2174-6419 Lex Social, vol. 11, núm. 2 (2021) 
Conviene, por último, retener que la problemática de la huelga política depende de la función atribuida al sindicato en el sistema político, porque si se trata de un sindicalismo profesional (sindicalismo económico) que desatiende la actividad política y sin pretensiones de cambio social no tiene sentido disponer del arma de la huelga política como medida de presión frente a los poderes públicos ${ }^{92}$. No es este el caso de nuestro sistema de relaciones laborales, toda vez que en el texto constitucional la huelga está llamada a ocupar un papel privilegiado en orden a la realización de los principios de la democracia y de la igualdad sustancial. De este modo la huelga queda vinculada a la participación de los trabajadores en la organización social, económica y política del país ${ }^{93}$.

En realidad, como ha sido advertido hace tiempo, el derecho de huelga permite la integración de los derechos de libertad con los derechos sociales, situándose como virtual derecho de dimensión sociopolítico. Por ello, el grado de garantía constitucional de las luchas del trabajo y de las posibilidades del legislador de intervenir depende, ante todo, de la interpretación política de la Constitución, sin que pueda ser un elemento impeditivo la ideología del Estado liberal que ha de ceder en la orientación marcada por el Estado

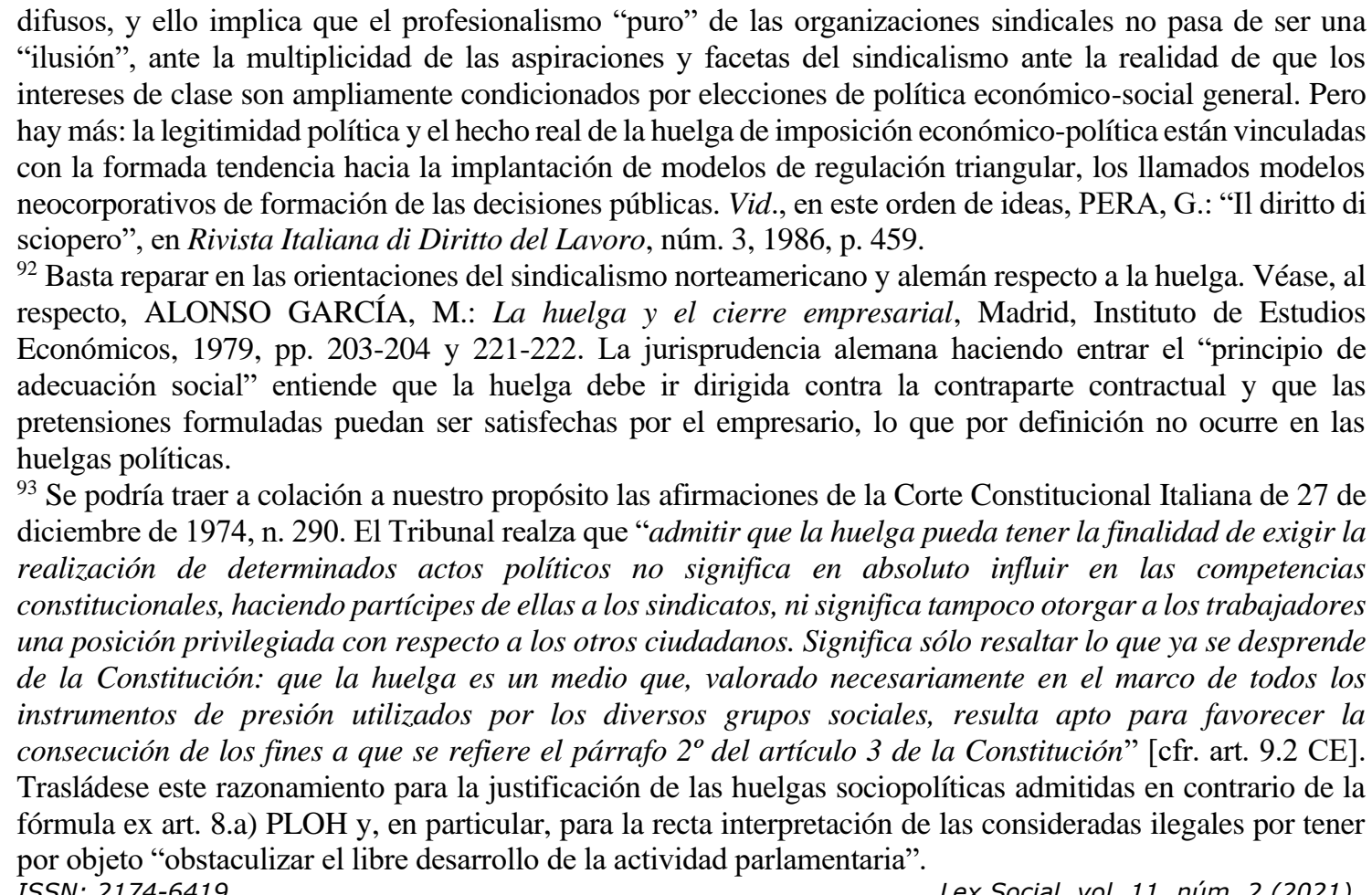
ISSN: 2174-6419

Lex Social, vol. 11, núm. 2 (2021) 
social y democrático de derecho ${ }^{94}$. Esto permite comprender como "el elemento 'politico' se filtra silenciosamente en huelgas o amenazas de huelgas"95.

En conclusión, se puede decir que el PLOHN venía a reflejar un modelo normativo sociopolítico de derecho de huelga. De acuerdo a este texto normativo, hubieran sido admisibles así las huelgas que estén motivadas por la pretensión de exigir a los poderes públicos la adopción o la modificación de una orientación política de carácter general o particular que incida en los intereses colectivos de los trabajadores como grupo específico o como clase social diferenciada en la estructura social global ${ }^{96}$.

Para terminar, no es inútil recordar las reflexiones hechas hace un siglo por los WEBB $^{97}$ que realzaban el dato empírico de que "la historia del sindicalismo es la historia de un Estado dentro de nuestro Estado" y que "la protección y otros muchos ideales políticos diferentes y a menudo contradictorios se ha apoderado en ocasiones de la imaginación de los asalariados organizados y han impreso su marca en el curso del movimiento sindical. Y, por lo menos desde 1867, donde quiera que esos ideales han dejado su huella en el sindicalismo, el sindicalismo ha dejado también su huella en la política".

\section{HUELGA LEGAL POR TENER PROYECCIÓN EN LAS RELACIONES LABORALES Y NO ÚNICAMENTE POR MOTIVOS POLÍTICOS: REFERENCIA A LA ÚLTIMA SENTENCIA DICTADA POR EL TRIBUNAL SUPREMO}

Hagamos referencia a la sentencia del Tribunal Supremo de fecha 15 de enero de $2020^{98}$ y que se refiere, entre otras cuestiones, a la legalidad o ilegalidad de las huelgas, así como al posible abuso en su ejecución ${ }^{99}$.

\footnotetext{
94 Vid. WIETHÖLTER, R.: Las fórmulas mágicas de la ciencia jurídica, trad., M. A. Extremoz, Madrid, Editorial de Derecho Reunidas, 1991, pp. 233 y ss. Realza el autor que al considerar ilegal la huelga política se ignora la politización del trabajo y de la economía que caracteriza nuestra sociedad, nuestra Constitución y nuestro Derecho, y que el problema actualmente no es, sin embargo, tanto establecer si los sindicatos y los trabajadores puede hacer una huelga política. En el centro del interés -también jurídico- no hay, por tanto, huelga política sino acciones y posiciones de los trabajadores y de sus asociaciones. Ello da cuenta de la inherencia de lo político en la lucha sindical.

95 WEBB, S. y WEBB, B.: Historia del sindicalismo, 1966-1920, trad. A. Gimeno, Madrid, Ministerio de Empleo y Seguridad Social, 1990, p. 615.

96 MONEREO PÉREZ, J. L.: "La constitucionalidad de las huelgas sociopolíticas (a propósito de la STC 36/1993, de 8 de febrero)", en AA. VV.: Homenaje al profesor Juan García Abellán, Murcia, Universidad de Murcia, 1994, p. 237.

97 WEBB, S. y WEBB, B.: Historia del sindicalismo, 1966-1920, trad. A. Gimeno, Madrid, Ministerio de Empleo y Seguridad Social, 1990, pp. 614-615.

${ }^{98}$ STS 15 de enero de 2020 [RJ 2020, 281].

99 CASTRO ARGÜELLES, Ma . A.: "La legalidad de las huelgas generales en contextos de tensiones políticas. Comentario a la Sentencia del Tribunal Supremo de 15 de enero de 2020", en Revista General de Derecho del Trabajo y de la Seguridad Social, núm. 56, 2020, versión electrónica. MONEREO PÉREZ, J. ISSN: 2174-6419 Lex Social, vol. 11, núm. 2 (2021)
} 
- Huelga política y libertad sindical: sobre los variados motivos para la convocatoria de la huelga

En ella, en relación a la libertad sindical, se alega que el sindicato no tenía legitimación suficiente para convocar una huelga general, pues el mismo ostentaba una representatividad del $0^{\prime} 48 \%$ en el territorio, por lo que carece de "implantación suficiente". Sin embargo, la facultad de convocatoria de huelga, como contenido de la libertad sindical, corresponde a las organizaciones sindicales, sin exigencia de que ostenten la cualidad de sindicatos más representativos (art. 2.2. LOLS), siendo suficiente con que tengan implantación en el ámbito laboral al que la huelga se extienda ${ }^{100}$; y es el ejercicio de otras facultades, lo que se reserva únicamente a los sindicatos que ostenten la condición de más representativos, de conformidad con los arts. 6 y 7 de la Ley Orgánica 11/1985, de 2 de agosto, de Libertad Sindical, no exigiéndose, por tanto, ostentar la condición de sindicato más representativo para tener facultad para convocar una huelga. En definitiva, no le es exigido al sindicato convocante que tenga implantación suficiente. Por tanto, teniendo una implantación del $0,48 \%$ en el ámbito del conflicto, el sindicato está legitimado para convocar una huelga.

Por otro lado, atendida la regulación legal y la interpretación jurisprudencial, resulta que no es ilegal una huelga por el hecho de que su objetivo no se limite exclusivamente a la defensa de los intereses de los huelguistas: "los intereses defendidos durante la huelga no tienen por qué ser necesariamente los intereses de los huelguistas, sino los intereses de la categoría de los trabajadores", debiendo atenderse a los intereses de los trabajadores en cuanto tales como motivos para convocar la huelga. En este sentido, cinco fueron los motivos para la convocatoria de la huelga y que traemos a colación ${ }^{101}$ :

$\left.1^{\circ}\right)$ Desde ya hace años los derechos laborales en el Estado Español están en clara regresión porque los criterios neoliberales se han impuesto. La máxima preocupación del capital es el mantenimiento de sus tasas de beneficios. En un contexto de economía globalizada y de un modelo productivo de bajo valor añadido, la apuesta es la reducción de costos salariales causante el empobrecimiento generalizado. A ello hay que añadir la crisis económica y social a partir de 2008 con la destrucción de un gran número de puestos de trabajo, incrementando la precariedad y el desplazamiento de amplias capas de la población hacia situaciones de miseria económica, con los riesgos que ello comporta. El modelo de salida de la crisis acaba siendo la cronificación de la crisis misma. Las últimas reformas laborales no son más que la cobertura jurídica necesaria para que este proceso se lleve a cabo en las mejores condiciones para el capital y la oligarquía aprovechando y ampliando el efecto disciplinario de las crisis. Se trata pues de debilitar tanto como sea

L. y ORTEGA LOZANO, P. G.: El derecho de huelga: configuración y régimen jurídico, Cizur Menor (Navarra), Aranzadi, 2019, passim.

${ }^{100}$ STC 11/1981, de 8 de abril, fj. 9 [RTC 1981\11].

101 STS 15 de enero de 2020 [RJ 2020, 281].

ISSN: $2174-6419$

Lex Social, vol. 11, núm. 2 (2021) 
posible a las clases trabajadoras (aislar, reducir derechos, desorganizar) y de imponer, si es preciso de forma coercitiva, los intereses del capital y la oligarquía.

$2^{\circ}$ ) Convocamos esta huelga general porque tenemos en cuenta la gran cantidad de personas trabajadoras que -reciente incorporadas al mercado laboral, o que hace años que forman parte del mismo, o bien que están a punto de salir- no pueden vivir de su salario. Desde el 2008 y, especialmente desde la reforma laboral de 2012, más que nunca, se han multiplicado el número de trabajadores/as que a pesar de cobrar un sueldo, no les resulta suficiente para afrontar sus gastos mensuales. Sueldos que obligan, por ejemplo, a escoger entre pagar el alquiler o pagar la universidad de un hijo/a. Convocamos la huelga para que desaparezca el precariado, porque las condiciones de trabajo de estas personas sean dignas. Estos salarios bajos, no sólo dificultan la vida de los trabajadores/as durante su vida laboral. La precariedad de esta masa de trabajadores/as asalariados ya está incidiendo, e incidirá, en el futuro en las personas que se jubilen. Quien haya sido trabajador/a precario, se convertirá sin posibilidad alguna de mejorar su situación, en un jubilado/a pobre. Sumando a esta inseguridad económica el desmantelamiento de la Seguridad Social, el futuro de las personas que han trabajado toda la vida no podrá ser más injusto y desolador

$3^{\circ}$ ) Aquello que entre los círculos políticos y económicos se ha denominado "salida de la crisis" no es más que otra de las muchas mentiras destinadas a convencer a los entes internacionales para evitar la vigilancia económica del Estado. Una mentira que, como la han repetido centenares de veces, creen que nos la hemos acabado creyendo, a pesar de que tengamos las pruebas -humanas y avientes- de lo contrario. Esa huelga es una prueba más de que no les creemos.

$4^{\circ}$ ) Convocamos esta huelga en contra de la anulación por parte del Tribunal Constitucional de las siguientes leyes sociales aprobadas por el Parlamento de Catalunya. Entendemos que estas leyes estaban destinadas a mejorar las condiciones de vida de las clases populares catalanas.

$5^{\circ}$ ) Por la derogación del Real Decreto-Ley 15/2017 de 6 de octubre de medidas urgentes en materia de movilidad de operadores económicos dentro del territorio nacional por su afectación negativa al tejido productivo y al mercado de trabajo.

Lo cierto es que, de manera general, se localizan varios motivos para la convocatoria de la huelga: ciertamente encontramos repuntes de motivos políticos; pero también es cierto que pueden localizarse contenidos fundamentados en materia sociolaboral. Analicemos cada una de ellas de manera individual.

El primero de los motivos sería una introducción y descripción del contexto general que se acompaña con la mención de la crisis económica de 2008, junto con algunas de sus consecuencias. Si bien son motivos legítimos, la realidad es que son argumentaciones 
amplias y generales, sin poder llegar a ser focalizadas a un interés profesional concreto respecto de los trabajadores afectados. De conformidad con la STS, "no puede ser calificado de "motivo" sino más bien de una especie de reflexión en la que se alude a la regresión de los derechos laborales, la economía globalizada, la reducción de costes salariales, la crisis económica y social que ha destruido gran número de puestos de trabajo, y ha incrementado la precariedad, las reformas laborales que son la cobertura para que el proceso se lleve a cabo en las mejores condiciones para el capital, el debilitamiento de la clase trabajadora". Como decíamos, dicha argumentación individualmente analizada y en términos estrictamente jurídicos, a nuestro juicio, caería como motivo justificado para convocar una huelga, pues el propio artículo 11 establece que la huelga es ilegal cuando se inicie "con cualquier otra finalidad ajena al interés profesional de los trabajadores afectados".

El segundo de los motivos sí se centra en términos jurídico-laborales, más concretamente, en las condiciones laborales de los trabajadores al referirse, expresamente, al sueldo, a la precariedad laboral, a las medidas de reforma iniciadas en 2008 (haciendo especial hincapié en la de 2012), al trabajo digno o decente, en la pensión de jubilación, entre otros supuestos. Aunque también es cierto que dicha argumentación se hace de manera general, echando en falta una mayor concreción al respecto y vinculación directa con el ejercicio de la actividad de los trabajadores. Para la STS, este motivo sí "alude explícitamente al objetivo de la huelga señalando que hay gran número de personas trabajadoras que no pueden vivir de su salario, especialmente desde la reforma de 2012, el precariado, la consecución de condiciones dignas de trabajo, el futuro de las personas que se jubilan, el desmantelamiento de la Seguridad Social...El contenido de este motivo contempla específicamente los derechos de las personas trabajadoras, refiriéndose a aspectos esenciales de las condiciones de trabajo como son los salarios, la precariedad laboral y el futuro de las pensiones de jubilación".

El tercer motivo, en nuestra humilde opinión, analizado de manera individual, también es algo escueto, haciendo referencia a decisiones políticas que, quizás, a través de una interpretación flexible, sí podría entenderse como relacionada o vinculada con los intereses profesionales de los trabajadores; no obstante, al igual que en el supuesto anterior, echamos en falta una mayor concreción y vinculación directa con el personal directamente afectado. Para el TS, en el motivo tercero se hace constar que la denominada "salida de la crisis por los círculos políticos y económicos es una mentira más y la huelga es una prueba de que no nos creemos la mentira. No se vislumbra en este motivo que haya un objetivo de la huelga, más allá de la denuncia de que la "salida de la crisis" es una mentira para convencer a los entes internacionales para evitar la vigilancia económica del Estado".

El cuarto de los motivos, a nuestro juicio, hubiera requerido, por parte de los convocantes, un desarrollo explícito de a qué condiciones o intereses profesionales afectan directamente. Dicho esto, para el Tribunal Supremo, "entre las clases populares 
catalanas cabe entender comprendidas a las personas trabajadoras, con lo que en el motivo de la huelga aparece no solo una finalidad política, sino también un objetivo de signo social'.

El quinto de los motivos, dónde también se pueden localizar atisbos de motivos políticos, también hubiera sido positivo una mayor concreción a ese tejido productivo y mercado de trabajo al que se refiere el motivo. Para el Tribunal Supremo, en el quinto motivo, "si bien aparecen motivos políticos", la "derogación del RD Ley 15/2017, de 6 de octubre, de medidas urgentes en materia de movilidad de operadores económicas dentro del territorio nacional, inmediatamente se vincula a razones sociales como es "su afectación negativa al tejido productivo y al mercado de trabajo", por lo que no es únicamente político este motivo dada su proyección en las relaciones laborales".

Analizados todos los motivos, de manera general y no de manera individualizada, teniendo en cuenta que el derecho a la huelga es un derecho fundamental (artículo 28.2 $\mathrm{CE}$ ), lo que implica que no puede hacerse una interpretación restrictiva del mismo, aun cuando se echa en falta un mayor enfoque y un concreto contenido en las fundamentaciones, y aunque se localiza ápices de motivos ideológicos y políticos, los mismos no terminan por desvirtuar el carácter esencial de este derecho fundamental, ni su finalidad primordial, por lo que no creemos conveniente que la misma sea considerara de huelga ilegal (aunque, reiteramos, hubiera sido positivo una mayor concreción en las alegaciones de los convocantes). En definitiva, los objetivos esenciales de la huelga se enfocan en los derechos de los trabajadores (y a otros objetivos). Por tanto, debe aceptarse que ciertos conflictos sociales (como la huelga) adquieren proyecciones extralaborales.

Y es que, el sistema que nace del artículo 28 CE es un sistema de "derecho de huelga". Esto quiere decir que determinadas medidas de presión de los trabajadores frente a los empresarios son un derecho de aquéllos. Es derecho de los trabajadores colocar el contrato de trabajo en una fase de suspensión y de ese modo limitar la libertad del empresario, a quien se le veda contratar otros trabajadores y llevar a cabo arbitrariamente el cierre de la Empresa ${ }^{102}$.

- Sobre la técnica de desconvocatorias sucesivas y el día que inicialmente va a llevarse a cabo la huelga

Establece el artículo 7.2 RDLRT que, "las huelgas rotatorias, las efectuadas por los trabajadores que presten servicios en sectores estratégicos con la finalidad de interrumpir el proceso productivo, las de celo o reglamento y, en general, cualquier forma de alteración colectiva en el régimen de trabajo distinta a la huelga, se considerarán actos ilícitos o abusivos". Más concretamente se hace referencia a la técnica de desconvocatorias sucesivas de la huelga por parte del sindicato convocante, huelga

102 STC 11/1981, de 8 de abril [RTC 1981\11]. 
que, inicialmente, estaba prevista para los días 30 de octubre hasta el 9 de noviembre de 2017.

Al hilo de lo anterior, en fecha 30/10/2017, tuvo entrada en el registro correspondiente escrito en el que se dejaba sin efecto la convocatoria de huelga para los días 30 y 31 de octubre, y de los días 1, 2, 3, 4 y 5 de noviembre, dejando el resto de días activos. Sin embargo, en fecha 03/11/2017, tuvo entrada en el registro correspondiente escrito en el que se dejaba sin efecto la convocatoria de huelga de los días 6 y 7 de noviembre, manteniéndose el resto de días. Posteriormente, en fecha 07/11/2017, tuvo entrada en el registro correspondiente escrito en que se deja sin efecto la convocatoria de huelga del día 9 de noviembre, manteniéndose el resto de días. Por tanto, la huelga se desarrolló el 8 de noviembre de 2017.

Sobre el concepto de abuso del derecho de huelga, el Tribunal Constitucional ha establecido que "los huelguistas tienen el derecho de incumplir transitoriamente el contrato, pero su ejercicio supone una limitación a la libertad del empresario y por ello exige una proporcionalidad y unos sacrificios mutuos, que hacen que cuando tales exigencias no se observen, las huelgas puedan considerarse abusivas"103.

Debe tenerse en cuenta que la huelga en días alternos o, más en general, la huelga intermitente, "no aparece expresamente citada entre aquellas que el artículo 7.2, del Real Decreto-ley 17/1977, de 4 de marzo, considera como actos ilícitos o abusivos y en consecuencia no les alcanza la presunción de abuso de derecho" 104 , como ocurre con las huelgas rotatorias, las efectuadas por los trabajadores que presten servicios en sectores estratégicos con la finalidad de interrumpir el proceso productivo y las de celo o reglamento. Como no es contrario a la Constitución que el legislador delimite, respetando en todo caso el contenido esencial del derecho de huelga, "aquellas modalidades que se presumen abusivas, la consecuencia derivada de su expresa inclusión en tal concepto consiste en desviar la carga de la prueba a los trabajadores que las utilicen, que deberán probar la ausencia de los requisitos precisos para la existencia del abuso. Por lo mismo, cuando la forma de huelga ejercitada no aparece expresamente incluida entre ellas, debe presumirse su validez y, sin que pueda excluirse que las circunstancias concurrentes lo conviertan en abusiva, corresponde la prueba del abuso de derecho a quien interese"105. Por ello se trata de una modalidad cuya validez debe presumirse y, sin que pueda excluirse que las circunstancias concurrentes la conviertan en abusiva, corresponde la prueba del abuso del derecho a quien interese, afirmándose que, para efectuar tal calificación, no basta con que la huelga origine un daño a la empresa, sino que es preciso que el daño sea grave y haya sido buscado por los huelguistas más allá de lo que es razonablemente

\footnotetext{
${ }^{103}$ STC 11/1981, de 8 de abril [RTC 1981\11].

${ }^{104}$ STC 41/1984, de 21 de marzo [RTC 1984141].

${ }^{105}$ STC 72/1982, de 2 de diciembre [RTC 1982172]. 
requerido por la propia actividad conflictiva y por las exigencias inherentes a la presión que la huelga necesariamente implica ${ }^{106}$.

Partiendo de que el derecho de huelga está reconocido como un derecho subjetivo de carácter fundamental a favor de los trabajadores precisamente para poder presionar a los empresarios en la obtención de sus intereses, y por su condición de derecho fundamental, las únicas huelgas que en principio tienen la condición de ilícitas y abusivas por presunción legal -salvando la existencia de huelgas ilegales por su finalidad expresa o por no haberse respetado en ellas las exigencias de la convocatoria y desarrollo previstas en el art. 11 del Real Decreto-ley 17/1977, de 4 de marzo, sobre relaciones de trabajoson las huelgas rotatorias, las efectuadas por los trabajadores que prestan servicios en sectores estratégicos con la finalidad de interrumpir el proceso productivo, y las de celo o reglamento ${ }^{107}$, con la consecuencia de que en todas las demás "debe de presumirse su validez $y$, sin que pueda excluirse que las circunstancias concurrentes la conviertan en abusiva, corresponde la prueba del abuso de derecho a quien interese". En ese concreto sentido, el hecho de que la licitud de la huelga no se presuma en la generalidad de los casos “no obsta, como es claro, a la potestad del Juez o Tribunal para valorar la prueba producida en el proceso y declarar los hechos probados. Pero impide que, en ausencia de conformidad sobre los hechos o de prueba, la presunción "iuris tantum" de licitud de la huelga deje de operar en perjuicio de los trabajadores, dado además que la carga de probar la existencia de los elementos fácticos de la huelga abusiva corresponde al empresario", añadiendo, además, que, "por otra parte, a los efectos de tal calificación no basta con que la huelga origine un daño a la empresa, sino que es preciso que el daño sea grave y que haya sido buscado por los huelguistas más allá de lo que es razonablemente requerido por la propia actividad conflictiva y por las exigencias inherentes a la presión que la huelga necesariamente implica". La huelga, en definitiva, es un derecho que tiene sus limitaciones y una de ellas es la de que no puede ejercerse de forma abusiva, pero con la particularidad de que recae sobre quien alega su carácter abusivo la carga de la prueba de aquellos elementos básicos necesarios para que la huelga pudiera ser calificada de abusiva por desproporcionada ${ }^{108}$.

En conclusión, únicamente, a las huelgas que el art. 7.2 del Real Decreto-ley 17/1977, de 4 de marzo, considera como actos ilícitos o abusivos les alcanza la presunción de abuso de derecho que comprende a las huelgas rotatorias, las efectuadas por los trabajadores que prestan servicios en sectores estratégicos con la finalidad de interrumpir el proceso productivo y las de celo o reglamento, presumiéndose la validez de otros tipos de huelga. Por tanto, corresponde a la empresa la prueba del abuso del derecho, afirmándose que, para efectuar tal calificación, no basta con que la huelga origine un daño a la empresa, sino que es preciso que el daño sea grave y haya sido buscado por los huelguistas más

\footnotetext{
106 STC 72/1982, de 2 de diciembre [RTC 1982\72].

107 STC 11/1981, de 8 de abril [RTC 1981\11], STC 72/1982, de 2 de diciembre [RTC 1982\72] y STC 41/1984, de 21 de marzo [RTC 1984\41].

108 STS 22 de noviembre de 2000 [RJ 2001\1430]. 
allá de lo que es razonablemente requerido por la propia actividad conflictiva. Sin embargo, no consta dato alguno que permita concluir que se ha producido un daño grave y buscado por los huelguistas más allá de lo que es razonablemente requerido por la propia actividad conflictiva, por lo que no ha existido abuso de derecho en la desconvocatoria de las huelgas llevada a cabo por el sindicato convocante ${ }^{109}$.

Todo lo anterior, en plena vinculación con la reciente sentencia del Tribunal Supremo, de fecha 15 de enero de 2020, nos lleva a confirmar que, cuando las huelgas poseen proyección en las relaciones laborales y no únicamente motivos políticos, la misma no es ilegal. Ciertamente, la huelga no se ha utilizado con una finalidad económica-social diferente de aquella que le ha sido atribuida por el propio ordenamiento jurídico; además, la misma tampoco puede considerarse abusiva por el hecho de desconvocarse para determinados días concretos.

\section{BALANCE Y PERSPECTIVAS: REFLEXIONES GENERALES}

El derecho de huelga debe ser garantizado, pero la dialéctica jurídica requiere que este derecho subjetivo de libertad no sea ilimitado ${ }^{110}$; limitaciones que deben producirse sin merma de su contenido esencial. De este aserto deriva el concepto mismo de ilicitud de huelga. Desde este punto de vista, se puede decir que una huelga puede ser ilícita por los fines que persigue. En atención a los fines autotutelados a través de la huelga, la noción de ilicitud de la misma depende en buena parte de la forma de garantía establecida en el ordenamiento jurídico. En este sentido, se ha de recordar que históricamente han podido ser adoptados dos enfoques o perspectivas distintas respecto al reconocimiento del derecho de huelga y a los valores fundamentales que está llamada a expresar ${ }^{111}$.

a) Una forma de garantía (reflejo de una orientación de política del Derecho) es elevar al más alto nivel el derecho de huelga y configurarlo como un derecho humano social y fundamental positivado en la Constitución. Tratándose de un derecho del ciudadano trabajador $y$, por tanto, de ese "hombre específico" al que se ha venido haciendo aquí referencia. Un derecho que encuentra su fuente en la Constitución y en preceptos de aplicación directa e inmediata, ejercitable como tal derecho de libertad en lo no prohibido por la ley, aunque esta no puede atentar el núcleo del derecho formado por su contenido esencial. Esta forma de reconocimiento permite abogar por una amplitud de los fines de la huelga, abarcando las huelgas de imposición económico-política para presionar sobre los poderes públicos. Es la perspectiva que adopta sin duda nuestro sistema constitucional. El derecho de huelga es un derecho "absoluto" (eficacia pasiva

\footnotetext{
${ }^{109}$ STS 15 de enero de 2020 [RJ 2020, 281].

${ }^{110}$ Vid. CALAMANDREI, P.: "Significato costituzionale del diritto di sciopero", en CALAMANDREI, P. (aut.) y CAPPELLETTI, M. (a cargo de): Opere Giuridiche, Vol. III., Napoli, Morano editore, 1965, p. 468. ${ }^{111}$ MONEREO PÉREZ, J. L. y ORTEGA LOZANO, P. G.: El derecho de huelga: configuración y régimen jurídico, Cizur Menor (Navarra), Aranzadi, 2019, pp. 250 y ss. 
personal generalizada) de la persona en su especificación como trabajador. Caracterización que, por otra parte, coincide con la función que en la historia moderna ha venido ocupando el instituto de la huelga. En fin, en este modelo de garantía del derecho de huelga, los fines que son legítimamente perseguibles mediante este medio de acción directa son instrumentales a su función jurídico-política ${ }^{112}$.

b) Desde otro punto de vista, la huelga queda privada de la consideración de derecho fundamental y se vincula estrictamente al ámbito de las relaciones profesionales entre empresarios y trabajadores. La huelga es ante todo un "arma contractual", utilizable tan sólo como "último recurso" de los trabajadores frente al empresario. Se vincula a la negociación colectiva y a los conflictos laborales únicamente suscitados en marco de la empresa $^{113}$. No parece necesario insistir, por el momento, en las consecuencias restrictivas que para el alcance del derecho de huelga tiene esta opción políticoorganizativa. Basta dejar constancia de la tendencia hacia la exclusión de las huelgas de imposición económico-política, las de solidaridad o apoyo y las que afecten a lo acordado en convenio colectivo.

De este modo, parece asistir la razón a KAHN FREUND ${ }^{114}$ cuando afirma que "la diferencia entre estos dos enfoques de la huelga, o como medio de presión en las relaciones laborales o como derecho humano fundamental, no es meramente un problema de teoría política (de política constitucional, ni posee sólo trascendencia práctica en relación a las huelgas que persiguen fines políticos). Si los trabajadores poseen un "derecho" de huelga, eso es algo más que una mera "libertad" frente a la responsabilidad criminal o civil, o frente a la intervención administrativa. Se trata de un derecho positivo al que no pueden renunciar, y especialmente no pueden hacerlo en el contrato de trabajo. El ejercicio de ese derecho tiene prioridad sobre cualquier estipulación contractual, lo que (...) puede tener importantes consecuencias prácticas".

Esta operativa práctico-jurídico revaloriza la importancia de individualizar jurídicamente el derecho de huelga: si es un derecho humano positivado al máximo nivel (configurado como derecho fundamental) o si es configurado simplemente como un derecho de libertad más, operante tan sólo en el ámbito de las relaciones laborales con los límites derivados de los principios jurídicos que entran en juego en este espacio de la vida social.

112 Se aproximan a este "modelo" de garantía constitucional los sistemas constitucionales de países como
Italia, Francia y España, en los cuales, la huelga viene reconocida como un derecho de libertad de la persona,
del ciudadano trabajador. Véase una interesante perspectiva de conjunto en VIDA SORIA, J.: "La regulación
del Derecho de huelga en los ordenamientos jurídicos de Francia e Italia", en AL, núm. 38, 1992, pp. 673 y ss.
MARTíNEZ ABASCAL, V., PÉREZ AMORÓS, F. y ROJO TORRECILLA, E.: "Experiencias de regulación
del derecho de huelga en algunos países de las Comunidades Europeas", en AA. VV.: La regulación del
derecho de huelga, Barcelona, IEL, 1988, pp. 38-40.
113 Es una forma de garantía jurídica de reconocimiento del derecho de huelga que impera en Estados Unidos,
Alemania, el Reino Unido, Canadá o Australia.
114 Vid. KAHN-FREUND, O.: Trabajo y Derecho, trad. y est. preliminar de J. M. Galiana Moreno, "In
Memoriam", por Faustino Cavas Martínez y José Luján Alcaraz, edición al cuidado de José Luis Monereo
Pérez, Madrid, Granada, Comares (Col. Crítica del Derecho), 2019, pp. 406 y ss.
ISSN: $2174-6419$
Lex Social, vol. 11, núm. 2 (2021) (cc) EY-NC-SA 
En la Carta Social Europea Revisada de 1996 (Estrasburgo, 3.V. 1996; y asimismo en la versión ya originaria de 1961) -verdadera “Constitución Social de Europa"- ${ }^{115}$ se garantiza el derecho de trabajadores a recurrir a medios de presión colectiva, incluido el derecho de huelga. Este derecho aparece especialmente vinculado al derecho de negociación colectiva (art. 6.4). Ahora bien, que la Carta contemple al derecho de huelga como institución complementaria de la negociación colectiva no comporta su negación como derecho humano fundamental, sino tan sólo un limitado reconocimiento instrumental en este instrumento internacional, que no prejuzga en nada una tal calificación, ni tampoco su configuración más generosa en los ordenamientos estatales ${ }^{116}$.

Por otra parte, conviene recordar aquí también que el derecho de huelga es reconocido como derecho humano fundamental en el art. 8.1.d) ${ }^{117}$ del Pacto Internacional de Derechos Económicos, Sociales y Culturales, de 19 de diciembre de 1966, ratificado en España por instrumento de 13 de abril de $1977^{118}$. Este texto pone de manifiesto, por si hubiera duda al respecto, que el derecho de huelga adquiere en esta sede el rango de un derecho humano positivado como derecho fundamental social (fórmula aquí de síntesis de los derechos de contenido económico y sociopolítico). El texto de Preámbulo no deja duda alguna al respecto. Veámoslo: "considerando que conforme a los principios enunciados en la Carta de las Nacionales, la libertad, la justicia y la paz en el mundo tienen por base el reconocimiento de la dignidad, inherente a todos los miembros de la familia humana y de sus derechos iguales e inalienables. Reconociendo que estos derechos se desprenden de la dignidad inherente a la persona humana (vinculación con la personalidad). Reconociendo que, con arreglo a la Declaración Universal de los Derechos Humanos, no puede realizarse el ideal de ser humano libre, liberado del temor y de la miseria, a menos que se creen condiciones que permitan a cada persona gozar de sus derechos económicos, sociales y culturales, tanto como de sus derechos civiles y políticos (nótese el reflejo de la construcción de los derechos sociales como "derechos condición"). Considerando que la Carta de las Naciones Unidas impone a los Estados la obligación de promover el respeto universal y efectivo de los derechos y libertades humanos (he aquí ahora el reflejo de la cláusula de efectividad). Comprendiendo que el individuo, por tener deberes respecto de otros individuos y de la comunidad a que

\footnotetext{
115 MONEREO PÉREZ, J. L. y TOMÁS JIMÉNEZ, N.: "Derecho de Huelga (Estudio del Artículo 6 de la Carta Social Europea), en MONEREO ATIENZA, C. y MONEREO PÉREZ, J. L. (Dirs. y coords.) et al: La garantía multinivel de los derechos fundamentales en el Consejo de Europa. El Convenio Europeo de Derechos Humanos y la Carta Social Europea, Granada, Comares, 2017, págs. 533 y sigs.

${ }^{116}$ Contra KAHN-FREUND, O.: Trabajo y Derecho, trad. y est. preliminar de J. M. Galiana Moreno, Madrid, Ministerio de Trabajo y Asuntos Sociales, 1987, pp. 409 y 410, para quien el derecho de huelga no es reconocido en la Carta "como un derecho humano fundamental (en cuanto tal no hubiera tenido cabida en la Carta)". Aparte de lo expresado en el texto esta opinión no puede ser compartida por la sencilla razón de que la Carta Social Europea reconoce verdaderos derechos sociales fundamentales no devaluados en relación a las libertades tradicionales.

${ }^{117}$ Según este artículo "los Estados Partes en el presente Pacto se comprometen a garantizar: (...) el derecho de huelga, ejercido de conformidad con las leyes de cada país”.

118 Repárese en la cláusula hermenéutica contenida en el art. 10.2 CE., y extráiganse de ello todas las consecuencias pertinentes que de ello razonablemente se deriven. 
pertenece está obligado a procurar la vigilancia y observancia de los derechos reconocidos en este Pacto".

En consecuencia, la huelga es un derecho del "hombre específico" (social y colectivamente situado) que está llamado a complementar a los derechos atribuidos al "hombre abstracto"119. Pero es que, además, su carácter de derecho de la persona (derecho subjetivo público de libertad) en su condición de trabajador contribuye a admitir su proyección erga omnes a fin de permitir la exigencia de pretensiones actuables frente al poder público y en el ámbito de las relaciones intersubjetivas privadas (las de trabajo). Como se puede comprobar la forma de garantía jurídica del derecho de huelga tiene una repercusión considerable en lo concerniente a la identificación de su ámbito objetivo. Éste, por tanto, es, en buena medida, un precipitado de la opción de política jurídica respecto a su configuración como derecho fundamental de libertad ejercitado colectivamente, esto es, en el marco inmanente de una acción colectiva ${ }^{120}$.

\section{BIBLIOGRAFÍA}

ALONSO GARCÍA, M.: La huelga y el cierre empresarial, Madrid, Instituto de Estudios Económicos, 1979.

ALONSO OLEA, M. y CASAS BAAMONDE, Mª E.: Derecho del Trabajo, Madrid, Civitas.

ARESE, C.: "Huelga con ocupación del lugar de trabajo", en BAYLOS GRAU, A. P., FLORENCIO THOMÉ, C. y GARCÍA SCHWARZ, R. (Coords.) et al: Diccionario internacional de derecho del trabajo y de la seguridad social, Valencia, Tirant lo Blanch, 2014.

BARREIRO GONZÁLEZ, G.: "Ensayo crítico sobre la paz laboral en el convenio colectivo con especial referencia a su carácter inmanente", en REDT, núm. 4, 1980.

BAYLOS GRAU, A.: Derecho de huelga y servicios esenciales, Madrid, Tecnos, 1988.

BAYLOS GRAU, A.: "Procedimientos de fijación de los servicios esenciales", en AA. VV.: Cuadernos de derecho judicial. El nuevo régimen jurídico de la huelga y el cierre patronal, Madrid, Consejo General del Poder Judicial, 1993.

\footnotetext{
119 Adviértase que la idea de "completar" se opone a la idea de "sustituir".

120 MONEREO PÉREZ, J. L.: "La huelga como derecho constitucional: la técnica específica de organización jurídico-constitucional de la huelga (II)", en Temas laborales: Revista andaluza de trabajo y bienestar social, núm. 28, 1993, p. 96. 
BAYLOS GRAU, A.: "Replanteamientos y novedades en la regulación jurídica de la huelga”, en Revista de Derecho Social, núm. 82, 2018.

BLANKE, T.: "Derecho de huelga de los servicios públicos en Alemania", en Gaceta Sindical, núm. 98, 1991.

BORRAJO DACRUZ, E.: "Poder normativo y poder judicial en la elaboración del nuevo Derecho del Trabajo", en $A L$, núm. 43, 1992.

BROWN, H. P.: Los orígenes del poder sindical, trad. A. Conde, Madrid, Ministerio de Trabajo y Seguridad Social, 1990.

CALAMANDREI, P.: "Significato costituzionale del diritto di sciopero", en CALAMANDREI, P. (aut.) y CAPPELLETTI, M. (a cargo de): Opere Giuridiche, Vol. III., Napoli, Morano editore, 1965.

CARINCI, F. et al.: Diritto del Lavoro. Vol. 1: Il Diritto Sindacale, Torino, UTET, 1983.

CASTRO ARGÜELLES, Ma . A.: "La legalidad de las huelgas generales en contextos de tensiones políticas. Comentario a la Sentencia del Tribunal Supremo de 15 de enero de 2020”, en Revista General de Derecho del Trabajo y de la Seguridad Social, núm. 56, 2020.

DAVID, M.: Les travailleurs et le sens de leur histoire, París, Cujas, 1967.

DE LA VILLA GIL, L. E., GARCIA BECEDAS, G. y GARCIA PERROTE ESCARTIN, I.: Instituciones de Derecho del Trabajo, Madrid, Ceura, 1991.

DEL REY GUANTER, S.: Negociación colectiva y paz laboral, Madrid, Instituto de Estudios Laborales, 1984.

DURÁN LÓPEZ, F.: "Derecho de huelga, sociedad civil y sociedad política”, en RIVERO LAMAS (coord.) et al: El derecho del trabajo ante el cambio social y político, Zaragoza, Universidad de Zaragoza, 1977.

DURÁN LÓPEZ, F.: "Huelga y servicios esenciales", en Revista de administración sanitaria siglo XXI, vol. 8, núm. 1, 2010.

ENGISCH, K.: Introducción al pensamiento jurídico, trad. E. Garzón Valdés, Madrid, Ediciones Guadarrama, 1967.

FLORENCIO THOMÉ, C.: "Huelga de solidaridad", en BAYLOS GRAU, A. P., FLORENCIO THOMÉ, C. y GARCÍA SCHWARZ, R. (Coords.) et al: Diccionario internacional de derecho del trabajo y de la seguridad social, Valencia, Tirant lo Blanch, 2014. 
GALLART FOLCH, A.: "Proyecciones extra-laborales en los conflictos colectivos de trabajo", en AA.VV.: Contratti collettivi e controversie collettive di lavoro. Studi in memoria di Lodovico Barassi, Padova, Cedam, 1965.

GARCIA BLASCO, J.: El derecho de huelga en España: calificación y efectos jurídicos, Barcelona, Bosch, 1983.

GARCÍA FERNÁNDEZ, M.: Manual de Derecho del Trabajo, Barcelona, Ariel, 1990.

GARCÍA RUBIO, Ma. A.: "Las modalidades de huelga ilegal”, en PÉREZ DE LOS COBOS Y ORIHUEL, F. (Dirs.) y MONREAL BRINGSVAERD, E. J. (Coord.), et al: Real Decreto-Ley 17/1977, de 4 de marzo, sobre relaciones de trabajo (Régimen legal y jurisprudencial de la huelga, el cierre patronal y el conflicto colectivo), Madrid, La Ley, 2014.

GERNIGON, B., ODERO, A. y GUIDO, H.: Principios de la OIT sobre el derecho de huelga, Ginebra, Oficina Internacional de Trabajo, 2000.

GIL y GIL, J. L.: "Ilegalidad e incumplimiento de servicios mínimos en la huelga", en REDT, núm. 39, 1989.

GIUGNI, G.: Derecho sindical, trad. y est. preliminar de J. Vida Soria y J. Montalvo Correa, Madrid, Ministerio de Trabajo y Seguridad Social, 1983.

GOLDTHORPE, J. H. (Comp.): Orden y conflicto en el capitalismo contemporáneo, trad. M. Fernández de Loaysa, Madrid, Ministerio de Trabajo y Seguridad Social, 1991.

GOÑI SEIN, J. L.: "La responsabilidad civil del sindicato por huelga”, en REDT, núm. 43, 1990.

GUINDO MORALES, S.: Acción de impugnación judicial, calificación y efectos de la extinción del contrato de trabajo por circunstancias objetivas, Murcia, Laborum, 2020.

GUINDO MORALES, S.: Caracterización jurídica y causas del despido objetivo en la normativa, doctrina y jurisprudencia tras las recientes reformas laborales, Granada, Comares, 2020.

JURADO SEGOVIA, Á.: "Negociación colectiva y derecho de huelga", en PÉREZ DE LOS COBOS ORIHUEL, F. (Dir.) y MONREAL BRINGSVAERD, E. (Coord.) et al: Real Decreto-Ley 17/1977, de 4 de marzo, sobre relaciones de trabajo (Régimen legal y jurisprudencial de la huelga, el cierre patronal y el conflicto colectivo), Madrid, La Ley, 2014. 
KAHN-FREUND, O.: "Il diritto di sciopero, la sua estensione e i suoi limiti", en $R D L$, núm. 4, 1978.

KAHN-FREUND, O.: Trabajo y Derecho, $2^{\mathrm{a}}$ ed., trad. y nota preliminar de J. Mª Galiana Moreno, "In Memoriam”, por Faustino Cavas Martínez y José Luján Alcaraz, edición al cuidado de J. L. Monereo Pérez, Granada, Comares (Col. Crítica del Derecho), 2019.

LASKI, H.J.: La libertad en el Estado moderno, edición, y estudio preliminar a cargo de J.L. Monereo Pérez, Granada, Comares (Col. Crítica del Derecho), 2020.

LEFRANC, G.: La huelga: historia y presente, Barcelona, Ed. Laia, 1972.

LÓPEZ-FANDO RAINAUD, J. R.: "Ejercicio del derecho de huelga. Modalidades lícitas, ilícitas y abusivas”, en AA. VV.: Cuadernos de derecho judicial. El nuevo régimen jurídico de la huelga y el cierre patronal, Madrid, Consejo General del Poder Judicial, 1993.

LÓPEZ GANDÍA, J.: "Huelgas ilegales y abusivas", en Revista del Instituto de Estudios Económicos (Ejemplar dedicado a "La regulación del Derecho de Huelga en España"), núm. 2 y 3, 2010.

MATÍA PRIM, SALA FRANCO, VALDÉS DAL-RÉ y VIDA SORIA: Huelga, cierre patronal y conflictos colectivos, Madrid, Civitas, 1982.

MARTÍN BERNAL, J. M.: El abuso del derecho, Madrid, Ed. Montecorvo, 1982.

MARTÍN SERRANO, A, L.: "La huelga de solidaridad", en AA. VV.: Jurisprudencia Constitucional y Relaciones Laborales, Madrid, Centro de Estudios Constitucionales, 1983.

MARTÍN VALVERDE, A.: "Huelga laboral y huelga política: un estudio de modelos normativos", en RIVERO LAMAS (coord.) et al: El derecho del trabajo ante el cambio social y político, Zaragoza, Universidad de Zaragoza, 1977.

MARTÍN VALVERDE, A.: "El derecho de huelga en la Constitución de 1978", en RPS, núm. 121, 1979.

MARTÍNEZ ABASCAL, V., PÉREZ AMORÓS, F. y ROJO TORRECILLA, E.: "Experiencias de regulación del derecho de huelga en algunos países de las Comunidades Europeas", en AA. VV.: La regulación del derecho de huelga, Barcelona, IEL, 1988.

MATIA PRIM, J., SALA FRANCO, T., VALDÉS DAL-RÉ, F. y VIDA SORIA, J.: Huelga, cierre patronal y conflictos colectivos, Madrid, Civitas, 1982. 
MENGONI, L.: "Corte constitucional italiana y Derecho sindical”, en $T L$, núm.19-20, 1990.

MERCADO NEUMANN, S.: "Huelga y convenio colectivo impropio", en REDT, núm. $50,1991$.

MONEREO PÉREZ, J. L.: "La huelga como derecho constitucional: la técnica específica de organización jurídico-constitucional de la huelga (I y II)", en Temas laborales: Revista andaluza de trabajo y bienestar social, núms. 27-28, 1993.

MONEREO PÉREZ, J. L.: "Las modalidades de huelga: la normalización jurídica de las llamadas huelgas anómalas (I y II)”, en Documentación Laboral, núms. 41 y 42, 1993 1994.

MONEREO PÉREZ, J. L.: "La constitucionalidad de las huelgas sociopolíticas (a propósito de la STC 36/1993, de 8 de febrero)", en AA. VV.: Homenaje al profesor Juan García Abellán, Murcia, Servicio de Publicaciones de la Universidad de Murcia, 1994.

MONEREO PÉREZ, J. L.: "La huelga (Artículo 28.2 CE)", en AA. VV.: Comentario a la Constitución Socio-Económica de España, Monereo Pérez, J.L., Molina Navarrete, C., y Moreno Vida, M.N. (Dirs. y Coords.), Granada, Comares, 2002.

MONEREO PÉREZ, J. L.: "El derecho a adoptar medidas de conflicto colectivo (Artículo 37.2 CE), en AA. VV.: Comentario a la Constitución Socio-Económica de España, Monereo Pérez, J.L., Molina Navarrete, C., y Moreno Vida, M.N. (Dirs. y Coords.), Granada, Comares, 2002.

MONEREO PÉREZ, J. L. (Coord.) et al: Derecho de huelga y conflictos colectivos. Estudio crítico de la doctrina jurídica, Granada, Comares, 2002.

MONEREO PÉREZ, J. L.: "El modelo normativo de huelga en la jurisprudencia del Tribunal Constitucional”, en CABEZA PEREIRO, J. y MARTÍNEZ GIRÓN, J. (Coords.) et al: El conflicto colectivo y la huelga. Estudios en homenaje al profesor Gonzalo Diéguez, Murcia, Laborum, 2008.

MONEREO PÉREZ, J. L.: La protección de los derechos fundamentales. El Modelo Europeo, Albacete, Bomarzo, 2009.

MONEREO PÉREZ, J. L.: "La titularidad del derecho de huelga y sus manifestaciones anómalas, ilegales o abusivas. Propuestas de reforma", en Revista del Instituto de Estudios Económicos (Ejemplar dedicado a "La regulación del Derecho de Huelga en España”), núm. 2 y 3, 2010.

MONEREO PÉREZ, J. L.: “Derecho de negociación y acción colectiva (Estudio del 
artículo 28)", en MONEREO ATIENZA, C. y MONEREO PÉREZ, J. L. (Dirs. y coords.) et al: La Europa de los derechos: estudio sistemático de la carta de los derechos fundamentales de la Unión Europea, Granada, Comares, 2012.

MONEREO PÉREZ, J. L. y TOMÁS JIMÉNEZ, N.: "Derecho de Huelga (Estudio del Artículo 6 de la Carta Social Europea), en MONEREO ATIENZA, C. y MONEREO PÉREZ, J. L. (Dirs. y coords.) et al: La garantía multinivel de los derechos fundamentales en el Consejo de Europa. El Convenio Europeo de Derechos Humanos y la Carta Social Europea, Granada, Comares, 2017.

MONEREO PÉREZ, J. L. y ORTEGA LOZANO, P. G.: El derecho de huelga: configuración y régimen jurídico, Cizur Menor (Navarra), Thomson/Aranzadi, 2019.

MONEREO PÉREZ, J. L. y ORTEGA LOZANO, P. G.: "Servicios mínimos con ocasión del ejercicio del derecho de huelga", en AA. VV.: Jurisprudencia Constitucional sobre trabajo y Seguridad Social, Tomo XXXVI: (2015-2018), Cizur Menor (Navarra), Aranzadi, 2019.

MONEREO PÉREZ, J. L. y ORTEGA LOZANO, P. G.: "Sustitución interna de trabajadores y utilización de medios técnicos no habituales en jornada de huelga", en AA. VV.: Jurisprudencia Constitucional sobre trabajo y Seguridad Social, Tomo XXXVI: (2015-2018), Cizur Menor (Navarra), Aranzadi, 2019.

MONEREO PÉREZ, J. L. y TOMÁS JIMÉNEZ, N.: "Derecho a Huelga (artículo 6 de la Carta Social Europea)", en MONEREO ATIENZA, C. y MONEREO PÉREZ, J. L. (Dirs. y Coords.) et al: La garantía multinivel de los derechos fundamentales en el Consejo de Europa. El Convenio Europeo de Derechos Humanos y la Carta Social Europea, Granada, Comares, 2017.

MONEREO PÉREZ, J. L., MOLINA NAVARRETE, C. y MORENO VIDA, M.N.: Manual de Derecho sindical, 12ª edición, Granada, Comares, 2017.

MORENO VIDA, Ma . N.: "Sobre la mediación extrajudicial previa como presupuesto de validez de la huelga y la ilegalidad de las huelgas novatorias", en Aranzadi Social: Revista Doctrinal, núm. 12, 2008.

MORENO VIDA, Ma . N.: La huelga en servicios esenciales, Cizur Menor (Navarra), Thomson/Aranzadi, 2007.

NAPOLI, M.: "El marco jurídico-institucional", en CELLA, G. P. y TREU, T. (a cargo de): Las relaciones industriales en Italia, trad. A. Gimeno, Madrid, Ministerio de Trabajo y Seguridad Social, 1991.

OJEDA AVILÉS, A.: Derecho Sindical, Madrid, Tecnos, 1990, $5^{\circ}$ edición. 
ORTEGA LOZANO, P. G. y GUINDO MORALES, S.: "Derecho de huelga y nuevas tecnologías: a propósito del esquirolaje interno y tecnológico", Nueva revista española de derecho del trabajo, núm. 225, 2019.

PALOMEQUE LÓPEZ, M. C.: "La huelga y el derecho de huelga en el proyecto de ley orgánica de huelga (PLOH): una reflexión general”, en AA. VV.: Cuadernos de derecho judicial. El nuevo régimen jurídico de la huelga y el cierre patronal, Madrid, Consejo General del Poder Judicial, 1993.

PERA, G.: "Il diritto di sciopero", en Rivista Italiana di Diritto del Lavoro, núm. 3, 1986.

PÉREZ DE LOS COBOS Y ORIHUEL, F.: "Sobre las limitaciones de la regulación jurisprudencial del derecho de huelga", en Revista del Ministerio de Empleo y Seguridad Social, núm. 108, 2014.

RAMÍREZ MARTÍNEZ, J. M.: "La huelga política", en AA. VV.: La huelga en España, Cuaderno núm. 2 del Instituto de Estudios Laborales, Madrid, 1975.

RAMÍREZ MARTÍNEZ, J. M.: "Huelga y cierre patronal en la Constitución española”, en AA. VV.: Estudios de Derecho del Trabajo en memoria del profesor Gaspar Bayón Chacón, Madrid, Civitas, 1980.

RAMOS QUINTANA, M. I.: "Conflicto de intereses, negociación colectiva y derecho de huelga: cambios en el sistema productivo y disrupción normativa”, en Revista de derecho social, núm. 83, 2018.

ROMANO, S.: Fragmentos de un Diccionario Jurídico, trad. S. Sentís Melendo y M. Ayerra Redín, edición al cuidado de J. L. Monereo Pérez, Granada, Comares (Col. Crítica del Derecho), 2002.

SALA FRANCO, T.: “Comentario al art. 82 ET”, en AA.VV.: El Estatuto de los Trabajadores, Madrid, 1981.

SALA FRANCO, T. y ALBIOL MONTESINOS, I.: Derecho Sindical, Valencia, Tirant lo Blanch, 1991.

SALCEDO BELTRÁN, C.: Negociación colectiva, conflicto laboral y Carta Social europea, Albacete, Bomarzo, 2014.

SEMPERE NAVARRO, A. V.: "Suspensión cautelar de huelga novatoria (el conflicto futbolístico)", en Nueva Revista Española de Derecho del Trabajo, núm. 176, 2015.

SEMPERE NAVARRO, A. V.: "Huelgas ilegales y huelgas abusivas", en SANGUINETI RAYMOND, W. y CABERO MORÁN, E. (Coords.) et al: Sindicalismo y Democracia. 
El Derecho Sindical Español del profesor Manuel Carlos Palomeque treinta años después (1986-2016), Granada, Comares, 2017.

SERRANO MARTÍNEZ, J. E.: "Titularidad y ejercicio del derecho de huelga: el papel de sindicato", en AA. VV.: Jurisprudencia constitucional y relaciones laborales, Madrid, Centro de Estudios Constitucionales, 1983.

SOSKICE, D.: "Oleadas de huelgas y explosiones salariales, 1968-70: Interpretación económica", en CROUCH, C. y PIZZORNO, A. (Coords.) et al: El resurgimiento del conflicto de clases en Europa occidental a partir de 1968. II. Análisis comparativo, trad. N. Sánchez Sainz-Trápaga, Madrid, Ministerio de Trabajo y Seguridad Social, Servicio de Publicaciones, 1991.

TREU, T.: “L'attività politica del sindicato”, en Politica del Diritto, núm. 2, 1975.

TUÑON DE LARA, M.: El movimiento obrero en la historia de España, Madrid, Taurus, 1972.

UGARTE CATALDO, J. L.: "Huelga política", en BAYLOS GRAU, A. P., FLORENCIO THOMÉ, C. y GARCÍA SCHWARZ, R. (Coords.) et al: Diccionario internacional de derecho del trabajo y de la seguridad social, Valencia, Tirant lo Blanch, 2014.

VALDÉS DAL-RÉ, F.: "Límites al derecho de huelga: apuntes críticos", en Cuadernos de Derecho del Trabajo, núm. 3, 1977.

VIDA SORIA, J.: "Régimen jurídico de la huelga en Italia", en AA.VV.: La huelga en Europa, en Cuadernos de Estudios Laborales, núm. 1, 1975.

VIDA SORIA, J.: "Génesis de las normas laborales en la Constitución Española de 1978", en AA. VV.: Estudios de Derecho del Trabajo en memoria del profesor Gaspar Bayón Chacón, Madrid, Civitas, 1980.

VIDA SORIA, J.: "Comentario al art. 28.2 de la Constitución Española", en ALZAGA VILLAAMIL, O. (Dir.) et al: Comentarios a las Leyes Políticas. Constitución Española de 1978, tomo III, Madrid, Edersa, 1983.

VIDA SORIA, J.: "La regulación del Derecho de huelga en los ordenamientos jurídicos de Francia e Italia”, en $A L$, núm. 38, 1992.

VIDA SORIA, J. y GALLEGO MORALES, Á.: “Art. 28. Derechos sindicales y de huelga", en ALZAGA VILLAAMIL, O. (Dir.) et al: Comentarios a la Constitución Española de 1978, tomo III (Arts. 24 a 38), Madrid, Edersa, 1996.

WEBB, S. y WEBB, B.: Historia del sindicalismo, 1966-1920, trad. A. Gimeno, Madrid, 
Ministerio de Empleo y Seguridad Social, 1990.

WIETHÖLTER, R.: Las fórmulas mágicas de la ciencia jurídica, trad., M. A. Extremoz, Madrid, Editorial de Derecho Reunidas, 1991.

ZANGARI, G.: "Diritto di sciopero e sindacto come "actore" político", en ZANGARI, G.: Il Dirito di sciopero, Milano, Giuffré, 1976. 